\title{
Ceramide and Regulation of Vascular Tone
}

\author{
Angel Cogolludo ${ }^{1,2, *(\mathbb{D})}$, Eduardo Villamor ${ }^{3}\left(\mathbb{D}\right.$, Francisco Perez-Vizcaino $^{1,2}$ and \\ Laura Moreno ${ }^{1,2}$ (D) \\ 1 Department of Pharmacology and Toxicology, School of Medicine, University Complutense of Madrid, \\ Instituto de Investigación Sanitaria Gregorio Marañón (IiSGM), Ciudad Universitaria S/N, 28040 Madrid, \\ Spain; fperez@med.ucm.es (F.P.-V.); lmorenog@med.ucm.es (L.M.) \\ 2 Ciber Enfermedades Respiratorias (CIBERES), 28029 Madrid, Spain \\ 3 Department of Pediatrics, Maastricht University Medical Center (MUMC+), School for Oncology and \\ Developmental Biology (GROW), 6202 AZ Maastricht, The Netherlands; e.villamor@mumc.nl \\ * Correspondence: acogolludo@med.ucm.es; Tel.: +34-913-94-71-20
}

Received: 20 November 2018; Accepted: 16 January 2019; Published: 18 January 2019

\begin{abstract}
In addition to playing a role as a structural component of cellular membranes, ceramide is now clearly recognized as a bioactive lipid implicated in a variety of physiological functions. This review aims to provide updated information on the role of ceramide in the regulation of vascular tone. Ceramide may induce vasodilator or vasoconstrictor effects by interacting with several signaling pathways in endothelial and smooth muscle cells. There is a clear, albeit complex, interaction between ceramide and redox signaling. In fact, reactive oxygen species (ROS) activate different ceramide generating pathways and, conversely, ceramide is known to increase ROS production. In recent years, ceramide has emerged as a novel key player in oxygen sensing in vascular cells and mediating vascular responses of crucial physiological relevance such as hypoxic pulmonary vasoconstriction (HPV) or normoxic ductus arteriosus constriction. Likewise, a growing body of evidence over the last years suggests that exaggerated production of vascular ceramide may have detrimental effects in a number of pathological processes including cardiovascular and lung diseases.
\end{abstract}

Keywords: ceramide; vascular; sphingolipids; reactive oxygen species; oxygen sensing; pulmonary; hypoxic pulmonary vasoconstriction; normoxic ductus arteriosus

\section{Introduction}

\subsection{Synthesis and Metabolism}

Sphingolipids are essential constituents of organelle and cell membranes that also play a key role in signal transductions of crucial physiological processes such as growth, differentiation, proliferation, migration, apoptosis, and cell death [1,2]. Ceramide represents a key point as the core of sphingolipid metabolism with a well-recognized involvement in many cellular functions. Ceramide can be generated through (Figure 1): (1) de novo pathway that synthesizes ceramide from serine and palmitoyl-CoA; (2) the activity of ceramide synthase; or (3) hydrolysis of sphingomyelin, catalyzed by a family of enzymes known as sphingomyelinases (SMases), which are classified into neutral SMases (nSMase 1, 2, and 3), acid SMase (aSMase), and alkaline SMase [1,3,4]. Once generated, ceramide can be hydrolyzed through the acid ceramidase giving rise to sphingosine, which in turn can be phosphorylated to sphingosine 1 phosphate (S1P) due to the action of sphingosine kinases (SK1 and SK2). 


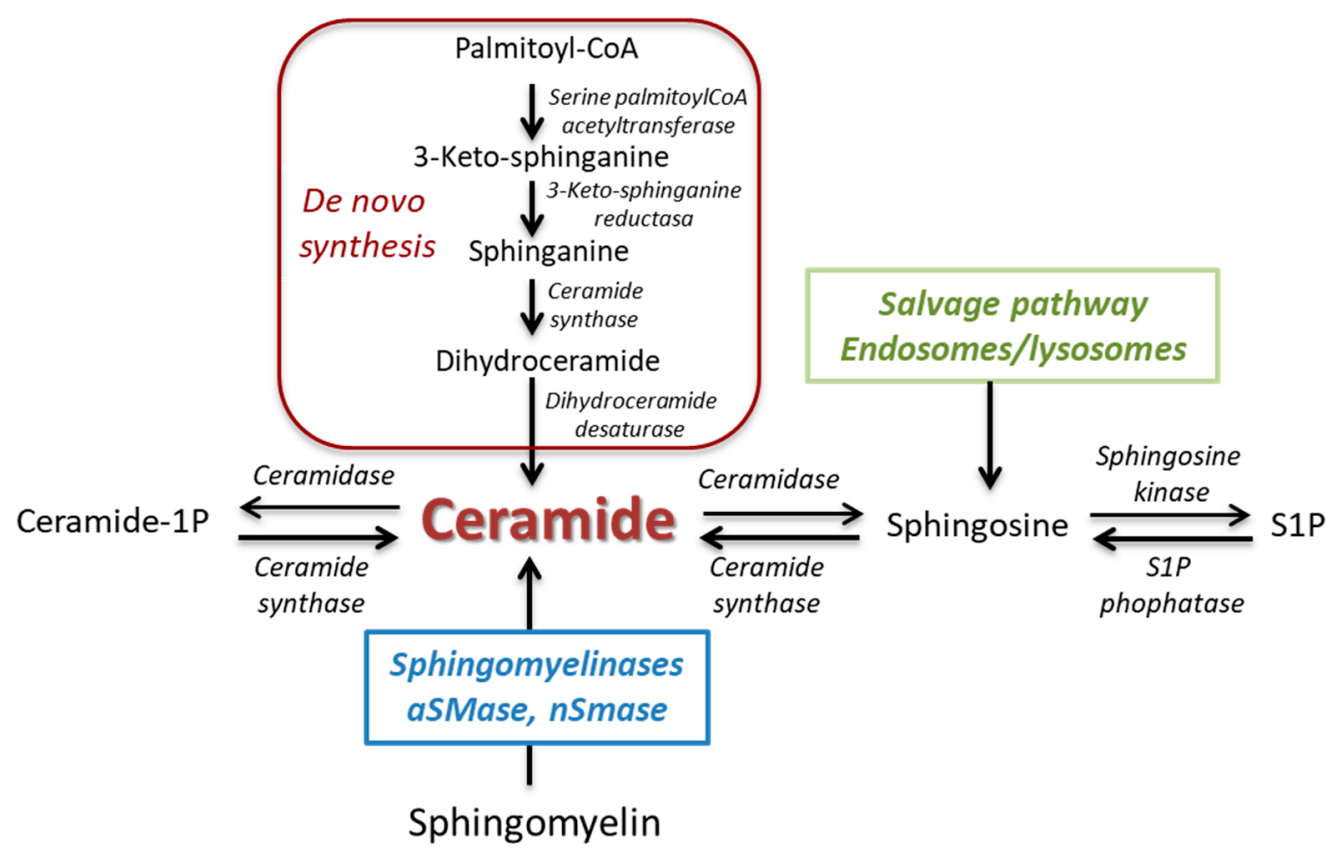

Figure 1. Synthesis and metabolism of ceramide.

\subsection{The Ceramide/S1P Rheostat}

Among the different sphingolipids, most research has focused on the bioactive S1P and ceramide. S1P acts as an autocrine or paracrine mediator by binding to specific membrane receptors $\left(\mathrm{S}_{1} \mathrm{P}_{1-5}\right)$, of which $\mathrm{S}_{\mathrm{P}} \mathrm{P}_{1-3}$ are expressed in the cardiovascular system [5,6]. Thus, S1P also exerts a wide range of cellular actions at the vascular level that depend on the type of receptor activated. These include proliferation, migration, and angiogenesis [7]. Likewise, S1P produces endothelium-dependent vasodilatation (via nitric oxide-NO) at low concentrations (nanomolar range), although at higher concentrations $(1-100 \mu \mathrm{M})$, such as those reached in the presence of thrombi, it produces vasoconstriction [8]. Ceramide has a prominent role in the regulation of programmed cell death (apoptosis) induced by tumor necrosis factor alpha (TNF- $\alpha$ ) or FAS ligand [9]. In addition to apoptosis, ceramide has been implicated in endothelial oxidative stress, growth inhibition, cytoskeleton changes, senescence, and vascular tone regulation [1,2,10-15]. Thus, ceramide and S1P are bioactive sphingolipids with opposite cell functions, which has led to the proposal of a 'sphingolipid rheostat', according to which the cell fate (death/survival) is determined by the balance between ceramide and S1P [2]. Both ceramide and S1P are thought to contribute to vascular tone regulation under physiological and pathological conditions [16]. While the role of S1P in vascular tone regulation has been the subject of a number of review articles [5,17-19], attention on ceramide has been disregarded. Thus, this review aims to delve deeper into the regulation of vascular tone by ceramide, with special emphasis on signal transduction pathways in endothelial and smooth muscle cells, leading to the activation of vasorelaxation and vasoconstriction responses, interaction with reactive oxygen species (ROS), involvement in oxygen sensing, and roles in pathological processes.

\section{Ceramide as Signaling Mediator Regulating Vasomotor Function}

The vasoactivity of ceramide has been investigated in several vascular preparations (Table 1). Common strategies in these studies to test the effects of increased cellular ceramide levels include the addition of exogenous cell-permeable ceramide analogs and the application of bacterial SMase from Bacillus cereus that cleaves membrane sphingomyelin and releases endogenous ceramide. Vasodilator, vasoconstrictor, or no response have been reported using either of these approaches (Table 1). 
Table 1. Summary of the vasomotor effects induced by ceramide. SMases: sphingomyelinases; KCa: calcium-activated $\mathrm{K}^{+}$channels; ROS: reactive oxygen species; PKC ;: protein kinase $\mathrm{C} \zeta$.

\begin{tabular}{|c|c|c|c|c|}
\hline Stimulus & Vascular Effect & Preparation & Mechanism & Ref. \\
\hline C2-ceramide & Transient vasodilation & Rat mesenteric arteries & $\begin{array}{l}\text { Activation of Guanylyl cyclase, } \\
\text { KCa channels }\end{array}$ & [20] \\
\hline C2-ceramide & Vasodilation & Rat aorta & Endothelium-derived NO & [21] \\
\hline C2-ceramide & Vasodilation & Rat aorta & Endothelium-independent & [22] \\
\hline $\begin{array}{l}\text { C2-ceramide, } \\
\text { SMase }\end{array}$ & Vasodilation & Rat aorta & $\begin{array}{l}\text { Inhibition of RhoA/Rho kinase } \\
\text { and Ca entry }\end{array}$ & [23] \\
\hline C2-ceramide & Vasoconstriction & $\begin{array}{l}\text { Small bovine coronary } \\
\text { arteries }\end{array}$ & Inhibition of Kca & [24] \\
\hline $\begin{array}{l}\text { SMase, C8 and } \\
\text { C16-ceramide }\end{array}$ & Vasoconstriction & canine cerebral arteries & PKC activation and Ca entry & [25] \\
\hline $\begin{array}{c}\text { SMase } \\
\text { C6-ceramide }\end{array}$ & Vasoconstriction & Rat pulmonary arteries & $\begin{array}{l}\text { PKC } \zeta \text { activation, Rho kinase } \\
\text { activation and decreased Ca entry }\end{array}$ & {$[26,27]$} \\
\hline $\begin{array}{c}\text { SMase } \\
\text { C6-ceramide }\end{array}$ & Vasoconstriction & $\begin{array}{l}\text { Rat and human pulmonary } \\
\text { arteries }\end{array}$ & $\begin{array}{l}\mathrm{PKC} \zeta \text { activation and Kv channel } \\
\text { inhibition }\end{array}$ & [28] \\
\hline $\begin{array}{c}\text { SMase } \\
\text { C6-ceramide }\end{array}$ & Vasoconstriction & $\begin{array}{l}\text { Chicken and human } \\
\text { pulmonary arteries and } \\
\text { ductus arteriosus }\end{array}$ & $\begin{array}{l}\mathrm{PKC} \zeta \text { activation and } \mathrm{Kv} \text { channel } \\
\text { inhibition }\end{array}$ & [29] \\
\hline C2-ceramide & Enhanced vasoconstriction & Rat aorta & Endoplasmic reticulum stress & [30] \\
\hline SMase & $\begin{array}{l}\text { Reduced vasodilation } \\
\text { Increased contraction to } \\
5-\mathrm{HT}\end{array}$ & Rat pulmonary arteries & IL-6 & [31] \\
\hline C2-ceramide & Attenuated vasodilation & Bovine coronary arteries & Increased ROS & [32] \\
\hline C2-ceramide & Attenuated vasodilation & Mice carotid arteries & Increased ROS & [33] \\
\hline $\begin{array}{l}\text { C6, C24:1 and } \\
\text { C24:0 ceramide }\end{array}$ & None & Canine cerebral arteries & & [25] \\
\hline
\end{tabular}

\subsection{Ceramide-Induced Vasodilation}

Several studies have shown a vasodilator effect induced by ceramide, however the mechanisms involved and the potential endothelial dependency remains controversial. A few studies have reported that vasodilation to ceramide is, at least partly, endothelium-dependent [21,34] and could involve the activation of endothelial nitric oxide synthase (eNOS) and subsequent NO generation [35]; even when most evidences point toward an impairment of endothelium-dependent vasodilation by ceramide (see Section 4.1). Nevertheless, vasodilation induced by ceramide and sphingomyelinase has also been found in endothelium denuded rat thoracic aortic rings [23,36] and rat mesenteric microvessels [20]. Inhibition of the RhoA/Rho-kinase pathway or activation of guanylyl cyclase and charybdotoxin-sensitive $\mathrm{K}^{+}$channels were proposed to contribute to these relaxant responses.

\subsection{Ceramide-Induced Vasoconstriction}

There is a number of studies indicating the ability of ceramide to promote vasoconstriction. Zheng T et al. [25] reported that nSMase, C8 ceramide and C16 ceramide induced a sustained vasoconstriction of canine cerebral arterial rings in a concentration-related manner that was endothelium independent. These responses were inhibited under $\mathrm{Ca}^{2+}$ free conditions and by verapamil and nimodipine, suggesting a role of $\mathrm{Ca}^{2+}$ entry through $\mathrm{L}$-type $\mathrm{Ca}^{2+}$ channels in ceramide-induced contraction. Interestingly, other ceramides tested in this preparation such as C6, C24:1, and C24:0 lacked vasoconstrictor effect [25] and C2-ceramide even attenuated vasoconstriction [37]. Inhibition of $\mathrm{K}^{+}$channels, which in turn depolarizes membrane potential leading to opening L-type $\mathrm{Ca}^{2+}$ channels, has been linked to ceramide-induced vasoconstriction in several studies. Thus, $\mathrm{C} 2$-ceramide was shown to inhibit calcium-activated $\mathrm{K}^{+}$channels $(\mathrm{KCa})$ channels and reduced the diameter of isolated perfused small bovine coronary arteries [24]. In rat, chicken, and human resistance pulmonary arteries, SMase and C6-ceramide induces contraction

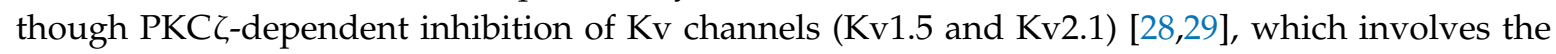


formation of a signaling complex PKC $\zeta-p 62-\mathrm{Kv} \beta[28,38,39]$ and is also associated with elevation of ROS [26]. These responses were also inhibited by nifedipine, which is consistent with a subsequent activation of L-type $\mathrm{Ca}^{2+}$ channels following Kv channel inhibition and depolarization. Additional mechanisms such as increase in calcium sensitization via Rho kinase activation and enhanced calcium entry through transient receptor potential canonical 6 (TRPC6) $[27,40]$ have also being involved in ceramide-induced pulmonary vasoconstriction. Importantly, nSMase-derived ceramide has been reported to potentiate vascular constriction [30] and to contribute to the vasoconstrictor responses induced by thromboxane $\mathrm{A}_{2}\left(\mathrm{TX}_{2}\right)$ [28], angiotensin II [41], and by changes in $\mathrm{O}_{2}$ tension (see Section 5) $[27,29,40]$.

In summary, the vascular effects of ceramide appear complex and somewhat puzzling. A number of factors may account for this variability including: (1) Differences in the strategy to enhance ceramide content (exogenously added vs. endogenous); (2) the interaction with different cell types (endothelial vs. smooth muscle cells); (3) the vascular diameter (conductance vs. resistance arteries); (4) the vascular territory (pulmonary vs. cerebral vs. coronary vs. mesenteric arteries); (5) the animal model; (6) the possible conversion of ceramide to other active sphingolipids such as S1P, which can lead to additional complexity; and (7) remarkably, the ceramide analogue tested (short-C2 vs. long C16). Many studies use short-chain ceramides (C2-ceramide and C6-ceramide) mainly because they are water-soluble and permeable to the cell membrane, unlike the natural long-chain ceramides. C2-ceramide is not suitable for mechanistic studies because it does not exist in plasma and shows different properties in comparing to C16-ceramide. The use of exogenous C6-ceramide may be a more adequate tool because, unlike $\mathrm{C} 2$-ceramide, it may induce the generation of endogenous long-chain ceramide (C16-ceramide), which was attributed to the recycling of the sphingosine backbone of C6-ceramide via deacylation/reacylation [3]. Nevertheless, the results obtained with long chain ceramides are expected to be more representative since they are more abundant, and their levels are altered in a number of pathological conditions (Tables 2-4).

\section{Ceramide and Redox Signaling}

ROS, including both free radicals (such as superoxide- $\mathrm{O}_{2}{ }^{-}$) and non-radical species (such as hydrogen peroxide- $\mathrm{H}_{2} \mathrm{O}_{2}$ ), play an essential role in the regulation of physiological and pathophysiological processes within the cardiovascular system [42-45]. In vessels, NADPH oxidases (Nox), mitochondrial electron transport chain (ETC), xanthine oxidase, and uncoupled endothelial NO synthase (eNOS) are considered main sources of ROS [43,45]. In addition to their role in proliferation, autophagy, or cytotoxicity, ROS are important modulators of vascular tone [43-46]. The activation of a variety of redox-sensitive signaling pathways comprising protein kinases, phosphatases, channels, and transporters may contribute to ROS-induced modulation of vascular smooth muscle tone. Remarkably, ROS can function as second messengers to mediate, or interfere with, the vasomotor effects of main vasoactive factors such as NO, prostacyclin, angiotensin II, endothelin- 1 , and TXA 2 [44,45,47]. In addition, it is well recognized that oxidative stress due to exaggerated ROS production or reduced antioxidant capacity may contribute to vascular diseases [44-46]. During the last decade accumulating evidence links ROS signaling either upstream or downstream ceramide production in vascular tissues [11,48-51].

\subsection{ROS-Induced Ceramide Production}

The ability of ROS to activate different ceramide generating pathways has been extensively studied in many cell types [52-55]. Thus, a number of reports have indicated that the generation of ROS in response to various stimuli such as antileukemic agents [56], stress [57], ischemia-reperfusion [58], pathogens [59], or hypoxia [26,27] may lead to ceramide accumulation. Both nSMase and aSMase are redox-sensitive enzymes whose activities are incremented by ROS [51,53,55]. Accumulation of ROS triggers the activation of aSMase in neutrophils [54], platelets [60], and splenocytes [61]. Likewise, activation of nSMase by ROS has been reported in vascular smooth muscle cells, fibroblasts, 
and airway epithelial cells $[26,62,63]$. Interestingly, SK1 an enzyme mediating the metabolic flow from ceramide to S1P is also redox-sensitive. Thus, ROS production may lead to a misbalance in the ceramide/S1P rheostat in either direction. Recently, Cinq-Frais et al. [62] showed that whereas low $\mathrm{H}_{2} \mathrm{O}_{2}$ concentrations trigger activation of nSMase2 and SK1 and subsequently S1P increase, high $\mathrm{H}_{2} \mathrm{O}_{2}$ levels inhibit SK1 leading to an increase in ceramide content. ROS-induced activation of this nSMase2/SK1 pathway has been also involved in the angiogenic signaling induced by oxidized LDL [64].

\subsection{Ceramide-Induced ROS}

Ceramide triggers the generation of ROS and increases oxidative stress in many mammalian cells and animal models $[33,50,51,65]$. In vascular cells or tissues, ceramide is known to enhance ROS production as a result of the activation of different redox enzymes including mitochondrial respiratory chain, NADPH oxidase, and uncoupled eNOS $[51,65,66]$. In vitro studies using isolated mitochondria [67] or endothelial cells $[68,69]$ have suggested a role of ceramide in the mitochondrial ROS production induced by TNF- $\alpha$ or circulating microparticles. Recently, it has been shown that long term exposition to ceramide leads to the increased formation of mitochondria-derived $\mathrm{H}_{2} \mathrm{O}_{2}$ in human resistance arterioles [70]. The cross talk between ceramide signaling pathway and NADPH oxidase-derived ROS has been reported in several vascular cells including rat [26] and human [71] vascular smooth muscle cells and endothelial cells [65,72]. Activation of NADPH oxidases has been associated with the formation of ceramide-enriched membrane rafts (MR). Thus, upon stimulation, ceramide-enriched MRs can be clustered to recruit NADPH oxidase subunits and form redox signaling platforms. In endothelial cells aSMase activates MR clustering to form redox signaling platforms in response to Fas ligand or TNF- $\alpha[73,74]$. Similar redox signaling platforms following nSMase activation has been shown in vascular smooth muscle cells [26].

\subsection{Feedforward Amplifying Mechanism}

As stated above, many studies point to a clear link between ROS and ceramide in which ROS are able to stimulate ceramide-generating enzymes and, conversely, the accumulation of ceramide triggers the production of ROS. These evidences support the view of the existence of feed-forward mechanism between these two key players [49,50]. Jaffrezou et al. [75] reported a positive feedback loop in which ceramide activated nSMase in myeloid leukemia cells. In endothelial cells, aSMase activates lipid raft clustering to form redox signaling platforms, where $\mathrm{O}_{2}{ }^{-}$production enhances aSMase activity, and thereby results in a forwarding amplification of redox signaling [73]. In pulmonary artery smooth muscle cells, Frazziano et al. [26] showed that $\mathrm{H}_{2} \mathrm{O}_{2}$ increases nSMase-derived ceramide production and, conversely, that ceramide increases $\mathrm{H}_{2} \mathrm{O}_{2}$, in line with the existence of a positive feedback cycle. Thus, a feedforward mechanism, which may involve aSMase- or nSMase-derived ceramide [50], leads to an amplification of ROS signaling which is thought to modulate vasomotor and endothelial function $[26,46,50,73,76]$.

\section{Ceramide and the Endothelium}

\subsection{Ceramide and Endothelial Dysfunction}

The endothelium plays an essential role in the control of vascular tone via the production of vasoactive factors $[77,78]$. Endothelial dysfunction involves an imbalance in the production of vasodilator and vasoconstrictor mediators and a transition to a prothrombotic phenotype [79]. A hallmark of endothelial dysfunction is reduced NO bioavailability, which can be due to a reduced synthesis of NO or to an increased breakdown of NO secondary to ROS production [78].

Ceramide has been proposed to exert dual (protective or deleterious) effects on endothelial cells [65]. Thus, activation of eNOS following an acute exposition to TNF- $\alpha$ was shown to involve the activation of nSMase in HeLa and human endothelial cells [80,81]. Moreover, incubation with ceramide 
increases eNOS phosphorylation [80] and expression [65]. Despite these results, most evidence points to a negative effect of ceramide on endothelial function. In fact, short-term incubation with exogenous ceramide impairs endothelium-dependent vasorelaxation, a functional characteristic of endothelial dysfunction, in both systemic [32,33,72] and pulmonary arteries [31]. Furthermore, inhibition of ceramide production prevents endothelial dysfunction induced by palmitate [82] or lipopolysaccharide [31] suggesting a role for ceramide in the endothelial dysfunction induced by inflammation or obesity. In line with these evidences, Smith et al. [83] have shown that nSMase activity chronically increased with age leading to elevated ceramide and ultimately eNOS inactivation and lower NO synthetic capacity with age. Moreover a chronic production of nSMase-derived ceramide has been involved in the transition from $\mathrm{NO}$ to $\mathrm{H}_{2} \mathrm{O}_{2}$ as the primary endothelial-dependent mediator in coronary artery disease [70].

Ceramide may contribute to the development of endothelial dysfunction by either reducing the synthesis of NO or by increasing its breakdown secondary to ROS production. A reduction in eNOS activity by ceramide has been reported either under basal conditions or following agonist stimulation. Thus, ceramide facilitates the interaction of eNOS with its negative regulator caveolin-1 [84] and promotes the dissociation of the complex Akt/Hsp90/eNOS, thereby preventing the phosphorylation of eNOS at positive regulatory sites (Ser1177) and potentiating the phosphorylation of eNOS at negative regulatory sites (i.e., Thr495) [82,83,85-87]. Recently, the activation of protein phosphatase $2 \mathrm{~A}$ (PP2A) has been proposed as a novel mechanism mediating the endothelial dysfunction following accumulation of ceramide in the context of type 2 diabetes and obesity $[87,88]$.

In addition, ceramide has also been shown to induce endothelial dysfunction by increasing ROS production and reducing NO bioavailability $[33,50,72,73,89]$. Several studies have confirmed that ceramide is able to induce a rapid translocation of the NAPDH oxidase subunit p47phox and promote its interaction with the gp91phox subunits leading to NADPH oxidase activation $[26,29,65,73,89]$. However, other studies suggest that ceramide is able to exert direct effects on the mitochondrial ETC, leading to increased ROS production in several cell types, including endothelial cells $[67,68,90]$. The resulting $\mathrm{O}_{2}{ }^{-}$can react with $\mathrm{NO}$ to form peroxynitrite $\left(\mathrm{ONOO}^{-}\right)$, which in turn can lead to eNOS uncoupling leading to a self-amplifying deleterious network [50]. Finally, accumulating evidence suggests that the activation of the NLPR3 inflammasomes and the production of inflammatory cytokines induced by ceramide also play a major role in the development of vascular dysfunction and atherosclerotic lesions [31,91-93].

\subsection{Ceramide and the Endothelial Barrier Function}

Endothelial barrier dysfunction leading to increased permeability and plasma leak to surrounding tissues is a common hallmark of several inflammatory diseases including sepsis, systemic inflammatory response syndrome (SIRS), or acute lung injury [94]. Whereas S1P plays a key role maintaining endothelial barrier integrity, accumulation of ceramide increases endothelial permeability [95-97]. The ability of ceramide to increase endothelial permeability was first demonstrated by Goggel et al. [98] in the context of the platelet-activating factor (PAF)-induced lung oedema. Since then, ceramide has been proved to mediate the increase in vascular permeability induced by a wide range of inflammatory stimuli, including lipopolysaccharide (LPS) or cigarette smoke $[31,95,96]$. Ceramide disrupts the pulmonary endothelial barrier function by inducing direct apoptotic effects on endothelial cells [13], although mechanisms unrelated to its apoptotic effects have also been involved [98]. Thus, ceramide has been shown to disrupt tight junctions via activation of Rho kinase [96] but independent of p38MAPK [95]. In addition, ceramide has been proposed to trigger the failure of the endothelial barrier by the recruitment of TRPC 6 channels and the subsequent increase in intracellular $\mathrm{Ca}^{2+}[95,99]$. These effects could be amplified by the concomitant reduction of eNOS activity [84,99], as described in the previous section. 


\section{Ceramide as a Key Oxygen- and Mechano-Sensing Mediator}

\subsection{Ceramide and Oxygen Sensing}

A number of cells are specialized in responding rapidly to changes in oxygen tension within the physiological range, playing a fundamental role in maintaining oxygen homeostasis [100-103]. Vascular smooth muscle cells from distal pulmonary arteries and from the ductus arteriosus (DA) belong to these specialized cell types that sense local $\mathrm{O}_{2}$ tension and respond to trigger vascular responses of crucial physiological relevance such as hypoxic pulmonary vasoconstriction (HPV) or normoxic DA constriction.

HPV is an adaptive physiological mechanism that allows ventilation/perfusion coupling [100-103]. While other factors may contribute, a great body of evidence strongly suggests that HPV is essentially an intrinsic feature of smooth muscle cells present in resistance pulmonary arteries in response to alveolar hypoxia [101]. The identification of the mechanisms involved in HPV has been a matter of intense debate during decades [101-104], with two main hypotheses being proposed. The redox hypothesis posed that the fall in $\mathrm{O}_{2}$ lead to a suppression of mitochondrial oxidative phosphorylation resulting in a more reduced cytosolic redox state and a decreased ROS production inducing the inhibition of $\mathrm{Kv}$ channels, membrane depolarization, and consequently the activation of voltage-gated $\mathrm{Ca}^{2+}$ channels and vasoconstriction $[103,105]$. Conversely the ROS hypothesis [106] proposed that hypoxia led to an increase in ROS (such as $\mathrm{O}_{2}{ }^{-}$or $\mathrm{H}_{2} \mathrm{O}_{2}$ ), which mediate vasoconstriction by targeting multiple potential mechanisms such as voltage-dependent (through L-type channels) and voltage-independent (through TRPC6 channels) $\mathrm{Ca}^{2+}$ entry [107], $\mathrm{Ca}^{2+}$ release from ryanodine-sensitive stores, and Rho kinase-mediated $\mathrm{Ca}^{2+}$ sensitization among others [101,104]. The source of ROS during hypoxia has also been a matter of controversy since both mitochondria and the NADPH oxidases were involved and even a positive feedback between these two sources has been proposed [76].

A decade ago, our group identified ceramide as a key player in HPV [27]. We provided evidence that the HPV responses ex vivo and in vivo require nSMase- but not aSMase-derived ceramide production. Hypoxia was shown to induce a rapid increase in ceramide within the pulmonary artery smooth muscle cells and this led to the inhibition of Kv currents [27], in line with the redox theory. However, this pathway was associated with an increase, rather than a decrease of ROS, according to the ROS hypothesis [26]. Hypoxia-induced ceramide production was prevented by the mitochondrial ETC inhibitor rotenone [26], in agreement with the proposal of the $\mathrm{O}_{2}$ sensor being located in mitochondria $[100,106,108]$. Interestingly, hypoxia-induced ROS production, $\mathrm{Kv}$ current inhibition and vasoconstriction were prevented by inhibitors of both mitochondrial ETC and NADPH oxidases [26]. Additionally, ceramide through its canonical target PKCᄃ [109] rapidly activated NADPH oxidase (via p47phox phosphorylation) to increase ROS production [26]. Altogether, these data led to a proposal of an integrated signaling pathway for HPV which included the mitochondrial ETC as the sensor and nSMase-PKC C-NADPH oxidase as a necessary redox amplification pathway required for ROS production and vasoconstriction (Figure 2). Interestingly, activation of this pathway was shown to contribute to $\mathrm{TXA}_{2^{-}}$(but not endothelin-1) induced pulmonary vasoconstriction [28]. In fact TXA 2 -induced vasoconstriction is associated with activation of PKC $[$ [39,110,111], ROS generation via NADPH oxidase [47], and inhibition of Kv currents [39,110,111]. The proposal of nSMase-PKC $\zeta-N A D P H$ oxidase as an amplification mechanism in HPV is in agreement with the ROS-induced ROS production mechanism reported for HPV [76] and with the dual role of ceramide as a product (being generated by redox-sensitive nSMAse) or as a trigger (by forming redox signaling platforms) of ROS production. Further evidence of the role of nSMase-derived ceramide in HPV was provided more recently by Tabeling et al. [40]. These authors showed that activation of nSMase by acute hypoxia leads to the translocation of TRPC 6 to caveolae, contributing to calcium mobilization and pulmonary vasoconstriction (Figure 2). TRPC6 recruitment to caveolae required the role of cystic fibrosis transmembrane conductance regulator (CFTR). As previously 
shown $[27,107,112]$, an increase in calcium sensitization by Rho kinase activation was also shown to contribute to HPV, although the conversion from ceramide to S1P could account for this effect [40]. Remarkably, ceramide-induced pulmonary vasoconstriction mimics HPV mechanistically as it is triggered through inhibition of Kv channels, activation of TRPC, or activation of Rho kinase $[27,28,40]$.

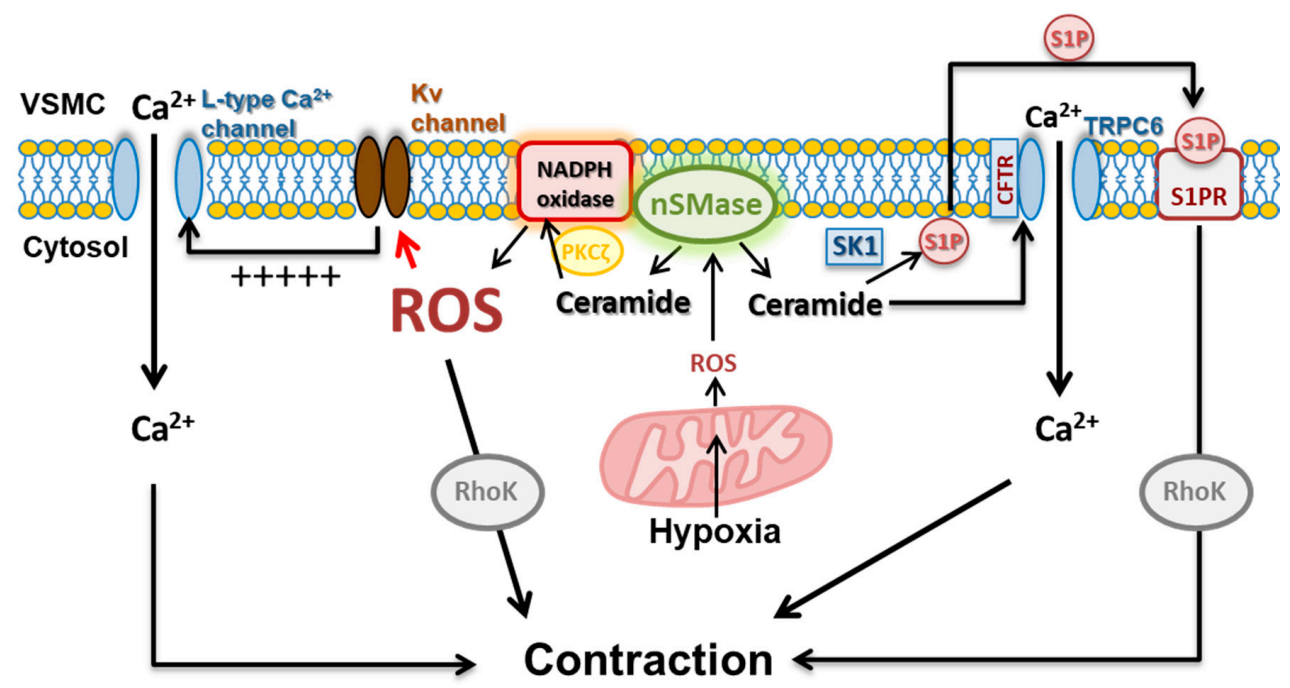

Figure 2. Schematic representation of the role of nSMase-derived ceramide in hypoxic pulmonary vasoconstriction (HPV). Hypoxia promotes mitochondria-derived ROS, which in turn stimulates the production of ceramide from nSMase. Ceramide amplifies ROS production through a PKC $\zeta$-dependent activation of NADPH oxidase. ROS inhibit $\mathrm{Kv}$ channels leading to membrane depolarization and activation of L-type $\mathrm{Ca}^{2+}$ channels, and activate RhoK-mediated $\mathrm{Ca}^{2+}$-sensitization. In addition, ceramide via CFTR stimulates $\mathrm{Ca}^{2+}$ entry through TRPC6 and, via a concomitant activation of SK1, leads to S1P generation which contributes to the contraction though the activation of RhoK. Black lines indicate a stimulatory effect, whereas the red line indicates an inhibitory effect. CFTR: cystic fibrosis transmembrane conductance regulator; Kv: voltage-gated $\mathrm{K}^{+}$channels; nSMase: neutral

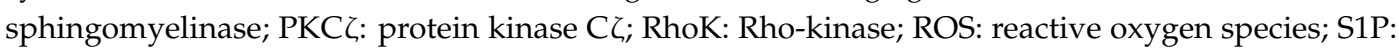
sphingosine-1-phosophate; S1PR: sphingosine-1-phosophate receptor; SK1: sphingosine kinase 1; VSMC: vascular smooth muscle cell. Black arrows indicate activation and red arrow indicates inhibition.

HPV represents a unique response of pulmonary arteries since in systemic arteries hypoxia induces vasorelaxation. Waypa et al. [108] showed that under hypoxia smooth muscle cells from both pulmonary or systemic arteries exhibited increases in mitochondrial-derived ROS, but functional responses were opposite (smooth muscle cells from pulmonary arteries exhibited an increase in intracellular $\mathrm{Ca}^{2+}$ while those from systemic arteries showed a decrease), and suggested the role of cell-specific expression of downstream signaling pathway. It is worth highlighting that hypoxia fails to generate ceramide in mesenteric arteries [27], suggesting the specificity of the nSMase pathway, that could serve as an amplification ROS signal in pulmonary but not in systemic arteries. The selective increased ceramide production in oxygen sensing vessels could be related to higher nSMase expression (i.e., nSMase2, [27,29]). Also, a closer localization of mitochondria to the plasmalemmal membrane in these cells [113] could facilitate the functional coupling between mitochondrial ROS and nSMase activation.

During fetal life, the DA connects the pulmonary artery with the aorta allowing venous blood to bypass the nonventilated lungs. Due to the fetal hypoxic environment the DA is tonically relaxed. At birth the increase in $\mathrm{O}_{2}$ tension is a key factor stimulating DA constriction, which precedes the anatomic and permanent closure of the vessel to establish the postnatal pattern of circulation [103,114]. A number of mechanisms have been reported to contribute to $\mathrm{O}_{2}$-induced DA constriction. Michelakis et al. [115] showed that $\mathrm{O}_{2}$-induced constriction was mediated through the inhibition of $\mathrm{Kv}$ channels, resulting in membrane depolarization, and $\mathrm{Ca}^{2+}$ entry through voltage-operated $\mathrm{Ca}^{2+}$ channels. Thereafter, 
these authors proposed a model in which the increase in $\mathrm{O}_{2}$ was sensed by the mitochondrial ETC (the sensor), leading to an increased production of ROS (i.e., $\mathrm{H}_{2} \mathrm{O}_{2}$, the mediator) resulting in $\mathrm{Kv}$ channel inhibition (the effector) [116]. Further studies confirmed the role of Kv channel inhibition $[117,118]$ and identified additional downstream effectors of the $\mathrm{O}_{2}$-sensing system such as $\mathrm{Ca}^{2+}$ sensitization of contractile proteins induced by Rho kinase activation or $\mathrm{Ca}^{2+}$ entry though TRPC channels $[117,119,120]$. Of note, the mechanisms involved in DA constriction resemble those for HPV despite being diametrically opposed stimuli suggesting the existence of a common signaling. Using a chicken embryo model, Moreno et al. [29] demonstrated that ceramide content was rapidly increased by hypoxia in pulmonary arteries and by normoxia in the DA. Likewise inhibition of nSMase using siRNA and pharmacological approaches markedly reduced HPV and normoxic DA contraction, strongly suggesting the role of ceramide as a common mediator in both responses. Remarkably, the involvement of nSMase-ceramide in acute oxygen sensing was also confirmed in human pulmonary arteries and DA [29].

Altogether, these studies are consistent with a prominent role of nSMase-derived ceramide in oxygen sensing in vascular tissues.

\subsection{Ceramide and Mechano-Sensing}

Vasodilation to shear stress (flow-induced dilation) is an important physiological mechanism linking vascular tone with the dynamics of fluid flow, which involves the endothelial production of vasoactive mediators (especially NO). Czarny $\mathrm{M}$ et al. [121] reported an acute mechanoactivation of nSMase in response to increased pulmonary blood flow, which was associated with an increase in ceramide content at the luminal endothelial cell surface primarily in caveolae. In a subsequent study, these authors showed the activation of the Akt/eNOS pathway by acute exposure to ceramide [122]. However, the role of nSMase-derived ceramide in flow-induced NO production or vasodilation has not been confirmed and even a potential deleterious effect of ceramide on flow-induced dilation has been proposed. Thus, Freed et al. [70] showed that chronic exposure to ceramide switched the vasoactive mediator of flow-induced dilation from $\mathrm{NO}$ to deleleterious reactive oxygen species such as $\mathrm{H}_{2} \mathrm{O}_{2}$, resembling what occurs in arterioles from coronary artery disease (CAD) patients. More recently, the formation of endothelium-derived extracellular vesicles by ceramide has recently been proposed as a mechanism leading to this transition [123]. Remarkably, inhibition of nSMase-derived ceramide formation in arterioles from $\mathrm{CAD}$ patients was shown to reverse the mediator of flow-induced dilation from the pro-atherogenic $\mathrm{H}_{2} \mathrm{O}_{2}$ to $\mathrm{NO}$, which is athero-protective [70]. Since flow-induced dilatation is a key determinant of myocardial blood flow distribution and its deterioration is a predictor of cardiovascular events, these studies suggest nSMase as a potential therapeutic target for pharmacological intervention and ceramide as a possible biomarker in the context of CAD.

\section{Ceramide and Disease}

Ceramides are essential components of every cell membrane and, therefore, any imbalance in their metabolism or the tissue accumulation of ceramide species may result in the activation of a number of different signaling pathways, many of which are detrimental to normal cellular function. A good example of the diversity of the potential deleterious effects of alterations in ceramide homeostasis is Farber disease (OMIM \#228000). Farber disease is caused by mutations in ASAH1 gene, which lead to decreased acid ceramidase activity and, in turn, to ceramide accumulation in almost every tissue of the body [124,125]. Farber disease has a heterogeneous presentation ranging from a severe phenotype with respiratory and neurological involvement and a very short life expectancy to a moderate phenotype, which generally includes joint swelling, contractures, and pain [124,125]. Besides these main symptoms, gastrointestinal, hepatological, cardiovascular, ophthalmological, dermatological, hematological, neuromuscular, and bone alterations are described in patients with Farber disease [124-126]. 
The evidence on the potential or actual involvement of ceramide metabolism in the etiopathogenesis of a growing number of conditions has been summarized and discussed in several very recent reviews and editorial comments. These conditions include, among others, cancer $[10,127,128]$, neurological, neurodegenerative, and psychiatric disorders $[7,15,57,129,130]$, infection/inflammation [131-134], metabolic conditions [135-138], cardiovascular disease [139-142], eye disease [143], skin disease [144,145], and lung disorders [4,14]. Although an exhaustive review is beyond the scope of this article, we will provide a brief description of the most relevant evidence from human studies on the role of ceramide in cardiovascular and pulmonary conditions.

\subsection{Ceramide and Cardiovascular Disease. The Role of Metabolic Syndrome}

Over the past few years an increasing number of studies have emerged revealing the association of circulating ceramide levels with adverse cardiovascular events such as myocardial infarction and stroke $[140,141]$. These studies consistently show that a subset of ceramides with long and very long chains (e.g., C16:0, C18:0, C20:0, C22:0, C24:1) almost invariably associate with deleterious outcomes and this association was independent of plasma lipid markers and other traditional cardiovascular risk factors [12,146-151] (Table 2). In contrast, C24:0 show no or negative relationships with adverse cardiovascular events. The ratio of the "harmful" ceramides against the "benign" C24:0 species has been proposed to be incorporated in the arsenal of biomarkers that predict cardiovascular disease $[140,141]$.

Table 2. Plasma levels of ceramide and cardiovascular disease.

\begin{tabular}{|c|c|c|}
\hline Study & Population & Main Findings \\
\hline $\begin{array}{c}\text { Tarasov et al. } 2014 \text { [146] } \\
\text { LURIC }\end{array}$ & $\begin{array}{l}\text { Males (258) with coronary artery disease who died } \\
\text { within } 3 \text { years of follow-up and } 187 \text { matched } \\
\text { control patients with coronary artery disease who } \\
\text { did not die during the follow-up. }\end{array}$ & $\begin{array}{l}\text { Higher plasmatic levels of C16:0, C18:0, C20:0, and C24:1, } \\
\text { and lower levels of C24:0 in patients who died. } \\
\text { Ratios of C16:0 /C24:0 and C22:0/C24:0 were significantly } \\
\text { related to increased risk of death in all subjects and } \\
\text { subgroups. C24:0/C24:1 was indicative of a reduced risk of } \\
\text { death, regardless of diabetes status. } \\
\text { Simvastatin lowered plasma ceramides. }\end{array}$ \\
\hline $\begin{array}{c}\text { Alshehry et al. } 2016 \text { [152] } \\
\text { ADVANCE }\end{array}$ & $\begin{array}{l}\text { Cohort of } 3799 \text { individuals with type } 2 \text { diabetes } \\
\text { that included } 698 \text { patients with cardiovascular } \\
\text { events and } 355 \text { with cardiovascular death. }\end{array}$ & Significant association between C24:1 and death. \\
\hline $\begin{array}{l}\text { Havulinna et al. } 2016 \text { [147] } \\
\text { FINRISK } 2002\end{array}$ & $\begin{array}{l}\text { Individuals ( } 8101 \text { ) from the FINRISK } 2002 \text { general } \\
\text { population cohort (men and women aged } 25 \text { to } 74 \\
\text { years). During a follow-up of } 13 \text { years, } 813 \text { subjects } \\
\text { experienced an incident major adverse } \\
\text { cardiovascular event, of which } 116 \text { were fatal. }\end{array}$ & $\begin{array}{l}\text { Levels of C16:0, C18:0, and C24:1 and the ratios C18:0/C24:0, } \\
\text { and C24:1/C24:0 were significantly higher in subjects with } \\
\text { an incident major adverse cardiovascular event compared } \\
\text { with asymptomatic subjects. } \\
\text { C18:0 holds the potential for improving the risk classification } \\
\text { over the Framingham risk score at a population level. } \\
\text { C16:0 and C24:1 associated with recurrent major adverse } \\
\text { cardiovascular event. }\end{array}$ \\
\hline $\begin{array}{l}\text { Wang et al. } 2017 \text { [148] } \\
\text { PREDIMED }\end{array}$ & $\begin{array}{l}\text { Participants (980) from the PREDIMED trial } \\
\text { (Prevención con Dieta Mediterránea), including } 230 \\
\text { incident cases of cardiovascular disease and } 787 \\
\text { randomly selected participants at baseline. }\end{array}$ & $\begin{array}{l}\text { Plasma concentrations of C16:0, C22:0, C24:0, and C24:1 } \\
\text { were positively associated with incident cardiovascular } \\
\text { disease risk. }\end{array}$ \\
\hline Mantovani et al. 2018 [149] & $\begin{array}{l}\text { Patients (581) with established or suspected } \\
\text { coronary artery disease undergoing stress } \\
\text { myocardial perfusion scintigraphy. }\end{array}$ & $\begin{array}{l}\text { Higher plasmatic levels of C18:0, C20:0, C22:0, and C24:1 } \\
\text { were associated with lower post stress anteroapical wall } \\
\text { perfusion. Associations persisted after adjustment for } \\
\text { conventional cardiovascular risk factors. }\end{array}$ \\
\hline $\begin{array}{l}\text { Anroedh et al. } 2018 \text { [150] } \\
\text { ATHEROREMO }\end{array}$ & $\begin{array}{l}\text { Patients (581) undergoing diagnostic coronary } \\
\text { angiography or percutaneous coronary } \\
\text { intervention for stable angina pectoris (SAP) or } \\
\text { acute coronary syndrome (ACS). }\end{array}$ & $\begin{array}{l}\text { C16:0 concentration was associated with major adverse } \\
\text { cardiac events after adjustment for cardiac risk factors, } \\
\text { clinical presentation, statin use, and HDL cholesterol level. } \\
\text { After multivariable adjustment, concentrations of C16:0, } \\
\text { C20:0, C24:1 and their ratios to C24:0 were associated with } \\
\text { the composite endpoint death or nonfatal acute coronary } \\
\text { syndrome. }\end{array}$ \\
\hline Meeusen et al. 2018 [12] & $\begin{array}{l}\text { Patients }(504) \text { between } 18 \text { and } 75 \text { years of age, who } \\
\text { were undergoing clinically indicated coronary } \\
\text { angiography. }\end{array}$ & $\begin{array}{l}\text { Concentrations of C16:0, C18:0, and C24:1 and their ratios to } \\
\text { C24:0 were significantly predictive for a combined outcome } \\
\text { of myocardial infarction, coronary artery bypass graft, } \\
\text { percutaneous intervention, stroke, and death at } 4 \text { years of } \\
\text { follow-up. } \\
\text { Concentrations of C16:0, C24:1 and the ratios C16:0/ C24:0, } \\
\text { C18:0 / C24:0, and C24:1/C24:0 were significantly predictive } \\
\text { for all-cause death at } 18 \text { years of follow-up and remained } \\
\text { significant after adjusting for cardiovascular risk factors. }\end{array}$ \\
\hline $\begin{array}{c}\text { de Carvalho et al. } 2018 \\
\text { [153] }\end{array}$ & $\begin{array}{l}\text { Two cohorts of patients ( } 337 \text { and } 119) \text { with acute } \\
\text { myocardial infarction, undergoing coronary } \\
\text { angiography. }\end{array}$ & $\begin{array}{l}\text { Identification of a 12-ceramide plasma prognostic signature } \\
\text { that predicted long-term major adverse cardiac and } \\
\text { cerebrovascular events in patients with acute myocardial } \\
\text { infarction, of which C22:1, C24:1 and dihydro C16:0 were the } \\
\text { strongest predictors. }\end{array}$ \\
\hline
\end{tabular}


The identification of the molecular mechanisms by which some particular ceramides drive cardiovascular dysfunction has received considerable attention but remains largely unknown. An important part of the link between ceramide and cardiovascular disease may operate through the metabolic syndrome [138]. The metabolic syndrome is a cluster of interconnected physiological, biochemical, clinical, and metabolic factors linked to an increased risk of cardiovascular diseases and type 2 diabetes mellitus [154]. Elevated blood pressure, atherogenic dyslipidemia (increased triglycerides and reduced high-density lipoprotein cholesterol), endothelial dysfunction, hypercoagulable state, insulin resistance, central obesity, and chronic stress are the several factors which constitute the syndrome [154]. Therefore, obesity, insulin resistance, type 2 diabetes mellitus, and cardiovascular disease form a pathologic continuum in which ceramide may be one of the most relevant connecting mediators through its capacity of disrupting insulin sensitivity, pancreatic $\beta$ cell function, vascular reactivity, and mitochondrial metabolism [138,155].

Despite the influence of dietary intake on the circulatory levels of lipids, plasma levels of lipid species are found to be heritable, and ceramides showed the greatest estimated heritability [156]. In addition, mutations in ceramide-modifying genes have been shown to associate with glycosylated hemoglobin (HbA1c), the most reliable marker of chronic hyperglycemia, [157] and increased risk of arterial and venous thrombosis in humans [156], and there is confirmatory evidence from relatively large human cohorts on the relationships between serum ceramides and insulin resistance $[158,159]$ (Table 3). Abundant experimental evidence from rodent models shows that inhibition or ablation of the enzymes involved in ceramide biosynthesis, as well as stimulation of ceramide degradation, are insulin sensitizing, antiatherogenic, and cardioprotective [138]. There is also experimental evidence on the role of different ceramide species in several atherosclerotic processes such as aggregation of lipoproteins, accumulation of lipoproteins and cholesterol within macrophages and vessel wall, impairment of mitochondrial function leading to excessive production of ROS, regulation of NO synthesis, activation of platelets, and expression of various cytokines [70,134,142,155]. Moreover, ceramides also modulate signaling and metabolic pathways involved not only on insulin resistance, but also on hepatic steatosis, and hypertension and, therefore, play a key role in the metabolic dysfunction that precedes cardiovascular events [138-140,160,161]. Finally, some ceramides may trigger cardiomyocyte-specific actions leading to the so termed lipotoxic cardiomyopathy $[155,160,162]$.

Table 3. Plasma levels of ceramide and insulin resistance.

\begin{tabular}{|c|c|c|}
\hline Study & Population & Main Findings \\
\hline Wigger et al. 2017 [158] & $\begin{array}{l}\text { Individuals (288) from the } \\
\text { D.E.S.I.R. cohort study (Data from } \\
\text { Epidemiological Study on the } \\
\text { Insulin Resistance syndrome) }\end{array}$ & $\begin{array}{l}\text { The susceptibility to develop type } 2 \\
\text { diabetes mellitus was associated with } \\
\text { increased plasma levels of C18:0, } \\
\text { C20:0, C22:0, and dihydro C22:0 }\end{array}$ \\
\hline Lemaitre et al. 2018 [159] & $\begin{array}{l}\text { Cohort of } 2086 \text { Native Americans } \\
\text { without diabetes (average age of } \\
38 \text { years), } 24 \% \text { of whom had a BMI } \\
\text { of } 35 \mathrm{~kg} / \mathrm{m}^{2} \text { or greater. }\end{array}$ & $\begin{array}{l}\text { Participants with higher (>90th } \\
\text { percentile) plasmatic levels of C16:0, } \\
\text { C18:0, C20:0, or C22:0 displayed } \\
\text { hyperinsulinemia and insulin } \\
\text { resistance }\end{array}$ \\
\hline
\end{tabular}

\subsection{Ceramide and Lung Diseases}

A growing body of evidence suggests an important role of sphingolipids in lung diseases, including pulmonary hypertension (PH), acute respiratory distress syndrome (ARDS), chronic pulmonary obstructive disease (COPD), asthma or cystic fibrosis, as reviewed elsewhere $[4,14,163,164]$. In this review, we will focus on those diseases with a direct effect on the pulmonary vascular circulation.

ARDS is characterized by the development of pulmonary edema which causes alveolar collapse and HPV failure leading to severe arterial hypoxemia. Furthermore, some patients develop mild to moderate PH which is independently associated with poor outcomes in patients with ARDS $[165,166]$ (Table 4). Patients in critical care show increased levels of ceramide-generating enzymes, including 
aSMase [167], and the role of ceramide in the development of pulmonary edema is well stablished in both patients and experimental models [98,168-170]. Furthermore, our group has recently described a potential association between ceramide and HPV failure in the context of ARDS [31]. Thus, a growing number of evidence appears to confirm that increased production of ceramides act as broad markers of lung injury.

Table 4. Ceramide and lung diseases.

\begin{tabular}{|c|c|c|}
\hline Study & Population & Main Findings \\
\hline \multicolumn{3}{|c|}{ High altitude pulmonary edema (HAPE) } \\
\hline Guo et al. 2015 [168] & 22 HAPE subjects and 22 healthy controls & $\begin{array}{l}\text { Plasma levels of C8-ceramide (and sphingosine) are increased } \\
\text { in HAPE subjects compared to subjects not developing any } \\
\text { symptoms after exposure to high altitude. }\end{array}$ \\
\hline \multicolumn{3}{|c|}{ Bronchopulmonary dysplasia (BPD) } \\
\hline $\begin{array}{c}\text { Laube et al. } 2017 \text { [171] } \\
\text { van Mastrigt et al. } 2018 \text { [172] }\end{array}$ & $\begin{array}{l}43 \text { preterm infants ( } 24-28 \text { weeks): } 25 \text { received } \\
\text { inhaled NO (iNO) and } 18 \text { placebo. } \\
122 \text { preterm babies ( }<32 \text { weeks): } 41 \text { developed BPD. }\end{array}$ & $\begin{array}{l}\text { aSMase activity in tracheal aspirates (TA) increases during the } \\
\text { first two weeks of life and this increase is more pronounced in } \\
\text { infants receiving iNOS. } \\
\text { Ceramide levels are increased in TA following mechanical } \\
\text { ventilation. } \\
\text { Ceramide profiles changed over time with mechanical } \\
\text { ventilation. Ceramide levels were lower in infants who } \\
\text { developed BPD as compared to those who did not. }\end{array}$ \\
\hline \multicolumn{3}{|c|}{ Congenital diaphragmatic hernia $(\mathrm{CDH})$ and development of chronic lung disease } \\
\hline Snoek et al. 2016 [173] & 72 neonates (>34 weeks) with CHD. & $\begin{array}{l}\text { Higher levels of ceramides (C18:1 and C24:0) in TA were } \\
\text { found in patients in conventional mechanical ventilation } \\
\text { compared to high-frequency oscillation. } \\
\text { Levels of ceramides were not associated with a higher risk of } \\
\text { mortality or chronic lung disease. }\end{array}$ \\
\hline \multicolumn{3}{|c|}{ Pulmonary arterial hypertension $(P A H)$} \\
\hline $\begin{array}{l}\text { Chen et al. } 2014 \text { [174] } \\
\text { Brittain et al. } 2016 \text { [175] }\end{array}$ & $\begin{array}{l}5 \text { PAH patients and } 5 \text { control subjects. } \\
19 \text { PAH patients and } 22 \text { control subjects. }\end{array}$ & $\begin{array}{l}\text { In lungs from PAH patients, levels of ceramide remains } \\
\text { unchanged but levels of S-1P and its receptor S1PR2 are } \\
\text { increased. } \\
\text { Ceramides C16:0 and C24:0 were increased in right ventricle } \\
\text { from PAH patients. }\end{array}$ \\
\hline \multicolumn{3}{|c|}{ Cystic fibrosis (CF) } \\
\hline $\begin{array}{l}\text { Guilbault et al. } 2009 \text { [176] } \\
\text { Garic et al. } 2017 \text { [177] } \\
\text { Brodlie et al. } 2010 \text { [178] }\end{array}$ & $\begin{array}{l}58 \text { patients with CF and } 72 \text { healthy control subjects. } \\
15 \mathrm{CF} \text { patients and } 15 \text { health volunteers. } \\
24 \text { patients undergoing lung transplantation with } \\
\mathrm{CF}(8) \text {, emphysema (8) or } \mathrm{PH}(8) \text {. }\end{array}$ & $\begin{array}{l}\text { Plasma levels of ceramide were decreased in patients with CF. } \\
\text { Plasma levels of C22:0, C24:0 and C26:0 were decreased in } \\
\text { patients with CF whereas C16:0 was increased. } \\
\text { Ceramide staining was increased in lungs from patients with } \\
\text { CF or emphysema as compared to those from PAH patients or } \\
\text { unused donors. C16:0, C18:0, and C20:0 (but not C22:0) were } \\
\text { significantly increased in lungs with CF vs. PAH. }\end{array}$ \\
\hline \multicolumn{3}{|c|}{ Chronic obstructive pulmonary disease (COPD) } \\
\hline $\begin{array}{l}\text { Lea et al. } 2016[179] \\
\text { Scarpa et al. } 2013[180] \\
\text { Bowler et al. } 2015[181]\end{array}$ & $\begin{array}{l}10 \text { patients with COPD and } 7 \text { controls ( } 5 \text { smokers). } \\
35 \text { patients with COPD and } 11 \text { nonsmoking } \\
\text { controls. } \\
250 \text { patients with COPD, } 122 \text { of them with } \\
\text { emphysema. }\end{array}$ & $\begin{array}{l}\text { Levels of C16:0, C18:0 and C20:0 might be increased in } \\
\text { alveolar macrophages from COPD patients. } \\
\text { Lung ceramide was increased in COPD patients but was not } \\
\text { related to the severity of the disease. } \\
\text { Plasma ceramide levels were inversely correlated with } \\
\text { emphysema severity whereas trihexosylceramide positively } \\
\text { correlated with COPD exacerbations. }\end{array}$ \\
\hline
\end{tabular}

However, clinical studies have uncovered a potential conflicting role of ceramide in acute versus chronic lung diseases. A good example can be found in the context of bronchopulmonary dysplasia (BPD). BPD is the most prevalent chronic lung disease during infancy, its incidence increases with the degree of prematurity and the pathology is characterized by a disruption of vascular development and alveolarization, with long term consequences [182]. PH develops in up to $40 \%$ of these patients and it is associated with a worst prognosis. Although our group has demonstrated the involvement of nSMase-derived ceramide in oxygen sensing during the neonatal period [29], only a limited number of studies have analyzed the potential link between sphingolipids and the risk of developing BPD. These studies consistently reported an increased in the levels of ceramide in tracheal aspirates in pediatric patients undergoing mechanical ventilation $[172,173]$. However, ceramide production tends to increase with postnatal development and this increase shows no or even a negative correlation with long term complications [171,172].

PH refers to a heterogeneous group of diseases, with a significant morbidity and mortality, which are characterized by a sustained elevation in pulmonary arterial pressure [183]. Vasoconstriction, remodeling of the pulmonary vessel wall, inflammation and thrombosis contribute to the increased pulmonary vascular resistance in PA in these patients. A link between the dysregulation of the 
ceramide/S1P rheostat and the development of $\mathrm{PH}$ has also been proposed. Thus, ceramide and/or S1P are involved in all the features associated with the development of $\mathrm{PH}$, including vasoconstriction $[27,29,31,40]$, inflammation [31] and proliferation of pulmonary artery smooth muscle cells [184]. In line with this, inhibition of SK1 prevents the development of hypoxia-induced PH in rodents [174]. However, despite these promising results, clinical data are still scarce on this topic. To the best of our knowledge, only a limited number of studies have analyzed the levels of ceramide and S1P in a limited number of patients with pulmonary arterial hypertension (PAH) (Table 4). Although these studies have not detected significant differences in the pulmonary levels of ceramide, an increase in S1P has been confirmed in both peripheral blood samples [185] and lung tissues from patients with PAH $[174,184,186]$. Notably, a recent report [175] suggests that ceramide levels are increased in the right ventricle of patients with PAH. These novel findings suggest that, in addition to pulmonary vascular abnormalities, accumulation of ceramide in the right ventricle may also contribute to the leading cause of death in $\mathrm{PAH}$, the failure of the right ventricle.

The development of $\mathrm{PH}$ is also a key determinant of poor prognosis in patients with COPD and cystic fibrosis $[187,188]$. nSMase is increased in the lungs from patients with emphysema [189] and increased ceramide production is found in lungs from patients with COPD or cystic fibrosis $[178,180]$. However, the levels of ceramide in the lungs were not found to be associated with the degree of severity of the disease $[179,180]$. In contrast, a negative correlation between plasmatic levels of ceramide and the development of emphysema has recently been found [181].

Although many questions remain to be answered, including the relative contribution of the ceramide/S1P rheostat in specific tissues (i.e., the lungs vs. the right ventricle or the systemic circulation), an increasing number of evidences suggest that the modulation of sphingolipids are a promising therapeutic target in pulmonary vascular diseases.

\section{Conclusions}

The present review provides consistent evidence of the role of ceramide in regulating vascular function. Ceramide exerts variable effects on vascular tone that reflect its involvement in a number of signaling pathways in different vascular cells. In particular, the vascular production of ceramide is closely related to the redox state, serving as amplification mechanisms of ROS signaling in physiological (oxygen sensing) or pathological (endothelial dysfunction) responses.

In recent years, the potential significance of ceramide in a wide variety of pathological entities has been investigated. There is still a considerable amount to be learned regarding ceramide signaling in vascular tissues, especially regarding the different ceramide subspecies, their source, their intracellular compartmentalization, and their participation in specific vascular responses.

Funding: This research was funded by Ministerio de Economía y Competitividad: SAF2016-77222-R; Instituto de Salud Carlos III: PI15/01100.

Acknowledgments: This work was supported by grants and fellowships by the Spanish Ministerio de Economia y Competitividad (SAF2016-77222-R to AC and to FP-V), Comunidad de Madrid (B2017/BMD-3727 to AC and LM) and Instituto de Salud Carlos III (PI15/01100 to LM), with funds co-financed by ERDF (FEDER) Funds from the European Commission, "A way of making Europe".

Conflicts of Interest: The authors have no conflicts of interest.

\section{References}

1. Hannun, Y.A.; Obeid, L.M. Principles of bioactive lipid signalling: Lessons from sphingolipids. Nat. Rev. Mol. Cell Biol. 2008, 9, 139-150. [CrossRef] [PubMed]

2. Van Brocklyn, J.R.; Williams, J.B. The control of the balance between ceramide and sphingosine-1-phosphate by sphingosine kinase: Oxidative stress and the seesaw of cell survival and death. Comp. Biochem. Physiol. $B$ Biochem. Mol. Biol. 2012, 163, 26-36. [CrossRef] [PubMed]

3. Kitatani, K.; Idkowiak-Baldys, J.; Hannun, Y.A. The sphingolipid salvage pathway in ceramide metabolism and signaling. Cell Signal 2008, 20, 1010-1018. [CrossRef] [PubMed] 
4. Petrache, I.; Berdyshev, E.V. Ceramide Signaling and Metabolism in Pathophysiological States of the Lung. Annu. Rev. Physiol. 2016, 78, 463-480. [CrossRef] [PubMed]

5. Li, N.; Zhang, F. Implication of sphingosin-1-phosphate in cardiovascular regulation. Front. Biosci. (Landmark Ed) 2016, 21, 1296-1313. [CrossRef]

6. Mazurais, D.; Robert, P.; Gout, B.; Berrebi-Bertrand, I.; Laville, M.P.; Calmels, T. Cell type-specific localization of human cardiac S1P receptors. J. Histochem. Cytochem. 2002, 50, 661-670. [CrossRef] [PubMed]

7. Chakrabarti, S.S.; Bir, A.; Poddar, J.; Sinha, M.; Ganguly, A.; Chakrabarti, S. Ceramide and Sphingosine-1Phosphate in Cell Death Pathways: Relevance to the Pathogenesis of Alzheimer's Disease. Curr. Alzheimer Res. 2016, 13, 1232-1248. [CrossRef]

8. Kennedy, S.; Kane, K.A.; Pyne, N.J.; Pyne, S. Targeting sphingosine-1-phosphate signalling for cardioprotection. Curr. Opin. Pharmacol. 2009, 9, 194-201. [CrossRef]

9. Hannun, Y.A. Functions of ceramide in coordinating cellular responses to stress. Science 1996, 274, 1855-1859. [CrossRef]

10. Garcia-Gonzalez, V.; Diaz-Villanueva, J.F.; Galindo-Hernandez, O.; Martinez-Navarro, I.; Hurtado-Ureta, G.; Perez-Arias, A.A. Ceramide Metabolism Balance, a Multifaceted Factor in Critical Steps of Breast Cancer Development. Int. J. Mol. Sci. 2018, 19. [CrossRef]

11. Li, P.L.; Gulbins, E. Bioactive Lipids and Redox Signaling: Molecular Mechanism and Disease Pathogenesis. Antioxid. Redox Signal. 2018. [CrossRef] [PubMed]

12. Meeusen, J.W.; Donato, L.J.; Bryant, S.C.; Baudhuin, L.M.; Berger, P.B.; Jaffe, A.S. Plasma Ceramides. Arterioscler. Thromb. Vasc. Biol. 2018, 38, 1933-1939. [CrossRef]

13. Petrache, I.; Natarajan, V.; Zhen, L.; Medler, T.R.; Richter, A.T.; Cho, C.; Hubbard, W.C.; Berdyshev, E.V.; Tuder, R.M. Ceramide upregulation causes pulmonary cell apoptosis and emphysema-like disease in mice. Nat. Med. 2005, 11, 491-498. [CrossRef] [PubMed]

14. Tibboel, J.; Reiss, I.; de Jongste, J.C.; Post, M. Sphingolipids in lung growth and repair. Chest 2014, 145, 120-128. [CrossRef] [PubMed]

15. Trayssac, M.; Hannun, Y.A.; Obeid, L.M. Role of sphingolipids in senescence: Implication in aging and age-related diseases. J. Clin. Investig. 2018, 128, 2702-2712. [CrossRef] [PubMed]

16. Fenger, M.; Linneberg, A.; Jorgensen, T.; Madsbad, S.; Sobye, K.; Eugen-Olsen, J.; Jeppesen, J. Genetics of the ceramide/sphingosine-1-phosphate rheostat in blood pressure regulation and hypertension. BMC Genet. 2011, 12, 44. [CrossRef] [PubMed]

17. Igarashi, J.; Michel, T. Sphingosine-1-phosphate and modulation of vascular tone. Cardiovasc. Res. 2009, 82, 212-220. [CrossRef] [PubMed]

18. Levkau, B. Sphingosine-1-phosphate in the regulation of vascular tone: A finely tuned integration system of S1P sources, receptors, and vascular responsiveness. Circ. Res. 2008, 103, 231-233. [CrossRef]

19. Kerage, D.; Brindley, D.N.; Hemmings, D.G. Review: Novel insights into the regulation of vascular tone by sphingosine 1-phosphate. Placenta 2014, 35, S86-S92. [CrossRef]

20. Czyborra, P.; Saxe, M.; Fetscher, C.; Meyer Zu Heringdorf, D.; Herzig, S.; Jakobs, K.H.; Michel, M.C.; Bischoff, A. Transient relaxation of rat mesenteric microvessels by ceramides. Br. J. Pharmacol. 2002, 135, 417-426. [CrossRef]

21. Johns, D.G.; Jin, J.S.; Webb, R.C. The role of the endothelium in ceramide-induced vasodilation. Eur. J. Pharmacol. 1998, 349, R9-R10. [CrossRef]

22. Zheng, T.; Li, W.; Wang, J.; Altura, B.T.; Altura, B.M. C2-ceramide attenuates phenylephrine-induced vasoconstriction and elevation in $\left[\mathrm{Ca}^{2+}\right] \mathrm{i}$ in rat aortic smooth muscle. Lipids 1999, 34, 689-695. [CrossRef] [PubMed]

23. Jang, G.J.; Ahn, D.S.; Cho, Y.E.; Morgan, K.G.; Lee, Y.H. C2-ceramide induces vasodilation in phenylephrineinduced pre-contracted rat thoracic aorta: Role of RhoA/Rho-kinase and intracellular $\mathrm{Ca}^{2+}$ concentration. Naunyn Schmiedebergs Arch. Pharmacol. 2005, 372, 242-250. [CrossRef] [PubMed]

24. Li, P.L.; Zhang, D.X.; Zou, A.P.; Campbell, W.B. Effect of ceramide on KCa channel activity and vascular tone in coronary arteries. Hypertension 1999, 33, 1441-1446. [CrossRef] [PubMed]

25. Zheng, T.; Li, W.; Wang, J.; Altura, B.T.; Altura, B.M. Sphingomyelinase and ceramide analogs induce contraction and rises in $[\mathrm{Ca}(2+)](\mathrm{i})$ in canine cerebral vascular muscle. Am. J. Physiol. Heart Circ. Physiol. 2000, 278, H1421-H1428. [CrossRef] [PubMed] 
26. Frazziano, G.; Moreno, L.; Moral-Sanz, J.; Menendez, C.; Escolano, L.; Gonzalez, C.; Villamor, E.; Alvarez-Sala, J.L.; Cogolludo, A.L.; Perez-Vizcaino, F. Neutral sphingomyelinase, NADPH oxidase and reactive oxygen species. Role in acute hypoxic pulmonary vasoconstriction. J. Cell Physiol. 2011, 226, 2633-2640. [CrossRef] [PubMed]

27. Cogolludo, A.; Moreno, L.; Frazziano, G.; Moral-Sanz, J.; Menendez, C.; Castaneda, J.; Gonzalez, C.; Villamor, E.; Perez-Vizcaino, F. Activation of neutral sphingomyelinase is involved in acute hypoxic pulmonary vasoconstriction. Cardiovasc. Res. 2009, 82, 296-302. [CrossRef]

28. Moral-Sanz, J.; Gonzalez, T.; Menendez, C.; David, M.; Moreno, L.; Macias, A.; Cortijo, J.; Valenzuela, C.; Perez-Vizcaino, F.; Cogolludo, A. Ceramide inhibits Kv currents and contributes to TP-receptor-induced vasoconstriction in rat and human pulmonary arteries. Am. J. Physiol. Cell Physiol. 2011, 301, C186-C194. [CrossRef]

29. Moreno, L.; Moral-Sanz, J.; Morales-Cano, D.; Barreira, B.; Moreno, E.; Ferrarini, A.; Pandolfi, R.; Ruperez, F.J.; Cortijo, J.; Sanchez-Luna, M.; et al. Ceramide mediates acute oxygen sensing in vascular tissues. Antioxid. Redox Signal. 2014, 20, 1-14. [CrossRef]

30. Zhang, H.; Li, J.; Li, L.; Liu, P.; Wei, Y.; Qian, Z. Ceramide enhances COX-2 expression and VSMC contractile hyperreactivity via ER stress signal activation. Vasc. Pharmacol. 2017, 96-98, 26-32. [CrossRef]

31. Pandolfi, R.; Barreira, B.; Moreno, E.; Lara-Acedo, V.; Morales-Cano, D.; Martinez-Ramas, A.; de Olaiz Navarro, B.; Herrero, R.; Lorente, J.A.; Cogolludo, A.; et al. Role of acid sphingomyelinase and IL-6 as mediators of endotoxin-induced pulmonary vascular dysfunction. Thorax 2017, 72, 460-471. [CrossRef] [PubMed]

32. Zhang, D.X.; Zou, A.P.; Li, P.L. Ceramide reduces endothelium-dependent vasodilation by increasing superoxide production in small bovine coronary arteries. Circ. Res. 2001, 88, 824-831. [CrossRef] [PubMed]

33. Didion, S.P.; Faraci, F.M. Ceramide-induced impairment of endothelial function is prevented by CuZn superoxide dismutase overexpression. Arterioscler. Thromb. Vasc. Biol. 2005, 25, 90-95. [CrossRef] [PubMed]

34. Jin, J.S.; Tsai, C.S.; Si, X.; Webb, R.C. Endothelium dependent and independent relaxations induced by ceramide in vascular smooth muscles. Chin. J. Physiol. 1999, 42, 47-51. [PubMed]

35. Mogami, K.; Kishi, H.; Kobayashi, S. Sphingomyelinase causes endothelium-dependent vasorelaxation through endothelial nitric oxide production without cytosolic Ca(2+) elevation. FEBS Lett. 2005, 579, $393-397$. [CrossRef] [PubMed]

36. Johns, D.G.; Osborn, H.; Webb, R.C. Ceramide: A novel cell signaling mechanism for vasodilation. Biochem. Biophys. Res. Commun. 1997, 237, 95-97. [CrossRef] [PubMed]

37. Zheng, T.; Li, W.; Altura, B.T.; Altura, B.M. C2-ceramide attenuates prostaglandin F2alpha-induced vasoconstriction and elevation of $\left[\mathrm{Ca}^{2+}\right] \mathrm{i}$ in canine cerebral vascular smooth muscle. Neurosci. Lett. 1998, 256, 113-116. [CrossRef]

38. Ishii, T.; Warabi, E.; Siow, R.C.M.; Mann, G.E. Sequestosome1/p62: A regulator of redox-sensitive voltage-activated potassium channels, arterial remodeling, inflammation, and neurite outgrowth. Free Radic Biol. Med. 2013, 65, 102-116. [CrossRef]

39. Moreno, L.; Frazziano, G.; Cogolludo, A.; Cobeno, L.; Tamargo, J.; Perez-Vizcaino, F. Role of protein kinase Czeta and its adaptor protein p62 in voltage-gated potassium channel modulation in pulmonary arteries. Mol. Pharmacol. 2007, 72, 1301-1309. [CrossRef]

40. Tabeling, C.; Yu, H.; Wang, L.; Ranke, H.; Goldenberg, N.M.; Zabini, D.; Noe, E.; Krauszman, A.; Gutbier, B.; Yin, J.; et al. CFTR and sphingolipids mediate hypoxic pulmonary vasoconstriction. Proc. Natl. Acad. Sci. USA 2015, 112, E1614-E1623. [CrossRef]

41. Bautista-Perez, R.; del Valle-Mondragon, L.; Cano-Martinez, A.; Perez-Mendez, O.; Escalante, B.; Franco, M. Involvement of neutral sphingomyelinase in the angiotensin II signaling pathway. Am. J. Physiol. Renal Physiol. 2015, 308, F1178-F1187. [CrossRef] [PubMed]

42. Aldosari, S.; Awad, M.; Harrington, E.O.; Sellke, F.W.; Abid, M.R. Subcellular Reactive Oxygen Species (ROS) in Cardiovascular Pathophysiology. Antioxidants 2018, 7. [CrossRef] [PubMed]

43. Briones, A.M.; Touyz, R.M. Oxidative stress and hypertension: Current concepts. Curr. Hypertens Rep. 2010, 12, 135-142. [CrossRef] [PubMed]

44. Montezano, A.C.; Dulak-Lis, M.; Tsiropoulou, S.; Harvey, A.; Briones, A.M.; Touyz, R.M. Oxidative stress and human hypertension: Vascular mechanisms, biomarkers, and novel therapies. Can. J. Cardiol. 2015, 31, 631-641. [CrossRef] [PubMed] 
45. Perez-Vizcaino, F.; Cogolludo, A.; Moreno, L. Reactive oxygen species signaling in pulmonary vascular smooth muscle. Respir. Physiol. Neurobiol. 2010, 174, 212-220. [CrossRef] [PubMed]

46. Knock, G.A.; Ward, J.P. Redox regulation of protein kinases as a modulator of vascular function. Antioxid. Redox Signal. 2011, 15, 1531-1547. [CrossRef] [PubMed]

47. Cogolludo, A.; Frazziano, G.; Cobeno, L.; Moreno, L.; Lodi, F.; Villamor, E.; Tamargo, J.; Perez-Vizcaino, F. Role of reactive oxygen species in $\mathrm{Kv}$ channel inhibition and vasoconstriction induced by TP receptor activation in rat pulmonary arteries. Ann. N. Y. Acad. Sci. 2006, 1091, 41-51. [CrossRef]

48. Bao, J.X.; Su, Y.T.; Cheng, Y.P.; Zhang, H.J.; Xie, X.P.; Chang, Y.M. Vascular sphingolipids in physiological and pathological adaptation. Front. Biosci. 2016, 21, 1168-1186.

49. Dumitru, C.A.; Zhang, Y.; Li, X.; Gulbins, E. Ceramide: A novel player in reactive oxygen species-induced signaling? Antioxid. Redox Signal. 2007, 9, 1535-1540. [CrossRef]

50. Li, P.L.; Zhang, Y. Cross talk between ceramide and redox signaling: Implications for endothelial dysfunction and renal disease. Handb. Exp. Pharmacol. 2013, 171-197. [CrossRef]

51. Li, X.; Becker, K.A.; Zhang, Y. Ceramide in redox signaling and cardiovascular diseases. Cell Physiol. Biochem. 2010, 26, 41-48. [CrossRef]

52. Martin, D.; Salinas, M.; Fujita, N.; Tsuruo, T.; Cuadrado, A. Ceramide and reactive oxygen species generated by $\mathrm{H}_{2} \mathrm{O}_{2}$ induce caspase-3-independent degradation of Akt/protein kinase B. J. Biol. Chem. 2002, 277, 42943-42952. [CrossRef] [PubMed]

53. Qiu, H.; Edmunds, T.; Baker-Malcolm, J.; Karey, K.P.; Estes, S.; Schwarz, C.; Hughes, H.; Van Patten, S.M. Activation of human acid sphingomyelinase through modification or deletion of C-terminal cysteine. J. Biol. Chem. 2003, 278, 32744-32752. [CrossRef] [PubMed]

54. Scheel-Toellner, D.; Wang, K.; Craddock, R.; Webb, P.R.; McGettrick, H.M.; Assi, L.K.; Parkes, N.; Clough, L.E.; Gulbins, E.; Salmon, M.; et al. Reactive oxygen species limit neutrophil life span by activating death receptor signaling. Blood 2004, 104, 2557-2564. [CrossRef] [PubMed]

55. Tsyupko, A.N.; Dudnik, L.B.; Evstigneeva, R.P.; Alessenko, A.V. Effects of reduced and oxidized glutathione on sphingomyelinase activity and contents of sphingomyelin and lipid peroxidation products in murine liver. Biochemistry 2001, 66, 1028-1034. [PubMed]

56. Bezombes, C.; Plo, I.; Mansat-De Mas, V.; Quillet-Mary, A.; Negre-Salvayre, A.; Laurent, G.; Jaffrezou, J.P. Oxidative stress-induced activation of Lyn recruits sphingomyelinase and is requisite for its stimulation by Ara-C. FASEB J. 2001, 15, 1583-1585. [CrossRef] [PubMed]

57. Jesko, H.; Stepien, A.; Lukiw, W.J.; Strosznajder, R.P. The Cross-Talk Between Sphingolipids and Insulin-Like Growth Factor Signaling: Significance for Aging and Neurodegeneration. Mol. Neurobiol. 2018. [CrossRef] [PubMed]

58. He, X.; Schuchman, E.H. Ceramide and Ischemia/Reperfusion Injury. J. Lipids 2018, 2018, 3646725. [CrossRef]

59. Li, C.; Wu, Y.; Riehle, A.; Orian-Rousseau, V.; Zhang, Y.; Gulbins, E.; Grassme, H. Regulation of Staphylococcus aureus Infection of Macrophages by CD44, Reactive Oxygen Species, and Acid Sphingomyelinase. Antioxid. Redox Signal. 2017. [CrossRef]

60. Charruyer, A.; Grazide, S.; Bezombes, C.; Muller, S.; Laurent, G.; Jaffrezou, J.P. UV-C light induces raft-associated acid sphingomyelinase and JNK activation and translocation independently on a nuclear signal. J. Biol. Chem. 2005, 280, 19196-19204. [CrossRef]

61. Dumitru, C.A.; Gulbins, E. TRAIL activates acid sphingomyelinase via a redox mechanism and releases ceramide to trigger apoptosis. Oncogene 2006, 25, 5612-5625. [CrossRef] [PubMed]

62. Cinq-Frais, C.; Coatrieux, C.; Grazide, M.H.; Hannun, Y.A.; Negre-Salvayre, A.; Salvayre, R.; Auge, N. A signaling cascade mediated by ceramide, src and PDGFRbeta coordinates the activation of the redox-sensitive neutral sphingomyelinase-2 and sphingosine kinase-1. Biochim. Biophys. Acta 2013, 1831, 1344-1356. [CrossRef] [PubMed]

63. Levy, M.; Castillo, S.S.; Goldkorn, T. nSMase2 activation and trafficking are modulated by oxidative stress to induce apoptosis. Biochem. Biophys. Res. Commun. 2006, 344, 900-905. [CrossRef] [PubMed]

64. Camare, C.; Auge, N.; Pucelle, M.; Saint-Lebes, B.; Grazide, M.H.; Negre-Salvayre, A.; Salvayre, R. The neutral sphingomyelinase-2 is involved in angiogenic signaling triggered by oxidized LDL. Free Radic. Biol. Med. 2016, 93, 204-216. [CrossRef] [PubMed] 
65. Li, H.; Junk, P.; Huwiler, A.; Burkhardt, C.; Wallerath, T.; Pfeilschifter, J.; Forstermann, U. Dual effect of ceramide on human endothelial cells: Induction of oxidative stress and transcriptional upregulation of endothelial nitric oxide synthase. Circulation 2002, 106, 2250-2256. [CrossRef] [PubMed]

66. Lecour, S.; Van der Merwe, E.; Opie, L.H.; Sack, M.N. Ceramide attenuates hypoxic cell death via reactive oxygen species signaling. J. Cardiovasc. Pharmacol. 2006, 47, 158-163. [CrossRef] [PubMed]

67. Garcia-Ruiz, C.; Colell, A.; Mari, M.; Morales, A.; Fernandez-Checa, J.C. Direct effect of ceramide on the mitochondrial electron transport chain leads to generation of reactive oxygen species. Role of mitochondrial glutathione. J. Biol. Chem. 1997, 272, 11369-11377. [CrossRef]

68. Corda, S.; Laplace, C.; Vicaut, E.; Duranteau, J. Rapid reactive oxygen species production by mitochondria in endothelial cells exposed to tumor necrosis factor-alpha is mediated by ceramide. Am. J. Respir. Cell Mol. Biol. 2001, 24, 762-768. [CrossRef]

69. Safiedeen, Z.; Rodriguez-Gomez, I.; Vergori, L.; Soleti, R.; Vaithilingam, D.; Douma, I.; Agouni, A.; Leiber, D.; Dubois, S.; Simard, G.; et al. Temporal Cross Talk Between Endoplasmic Reticulum and Mitochondria Regulates Oxidative Stress and Mediates Microparticle-Induced Endothelial Dysfunction. Antioxid. Redox Signal. 2017, 26, 15-27. [CrossRef]

70. Freed, J.K.; Beyer, A.M.; LoGiudice, J.A.; Hockenberry, J.C.; Gutterman, D.D. Ceramide changes the mediator of flow-induced vasodilation from nitric oxide to hydrogen peroxide in the human microcirculation. Circ. Res. 2014, 115, 525-532. [CrossRef]

71. Bhunia, A.K.; Han, H.; Snowden, A.; Chatterjee, S. Redox-regulated signaling by lactosylceramide in the proliferation of human aortic smooth muscle cells. J. Biol. Chem. 1997, 272, 15642-15649. [CrossRef] [PubMed]

72. Zhang, D.X.; Zou, A.P.; Li, P.L. Ceramide-induced activation of NADPH oxidase and endothelial dysfunction in small coronary arteries. Am. J. Physiol. Heart Circ. Physiol. 2003, 284, H605-H612. [CrossRef] [PubMed]

73. Zhang, A.Y.; Yi, F.; Jin, S.; Xia, M.; Chen, Q.Z.; Gulbins, E.; Li, P.L. Acid sphingomyelinase and its redox amplification in formation of lipid raft redox signaling platforms in endothelial cells. Antioxid. Redox Signal. 2007, 9, 817-828. [CrossRef] [PubMed]

74. Zhang, C.; Li, P.L. Membrane raft redox signalosomes in endothelial cells. Free Radic. Res. 2010, 44, 831-842. [CrossRef] [PubMed]

75. Jaffrezou, J.P.; Maestre, N.; de Mas-Mansat, V.; Bezombes, C.; Levade, T.; Laurent, G. Positive feedback control of neutral sphingomyelinase activity by ceramide. FASEB J. 1998, 12, 999-1006. [CrossRef] [PubMed]

76. Rathore, R.; Zheng, Y.M.; Niu, C.F.; Liu, Q.H.; Korde, A.; Ho, Y.S.; Wang, Y.X. Hypoxia activates NADPH oxidase to increase [ROS]i and $\left[\mathrm{Ca}^{2+}\right] \mathrm{i}$ through the mitochondrial ROS-PKCepsilon signaling axis in pulmonary artery smooth muscle cells. Free Radic Biol. Med. 2008, 45, 1223-1231. [CrossRef]

77. Cogolludo, A.; Moreno, L.; Villamor, E. Mechanisms controlling vascular tone in pulmonary arterial hypertension: Implications for vasodilator therapy. Pharmacology 2007, 79, 65-75. [CrossRef] [PubMed]

78. Vanhoutte, P.M.; Zhao, Y.; Xu, A.; Leung, S.W. Thirty Years of Saying NO: Sources, Fate, Actions, and Misfortunes of the Endothelium-Derived Vasodilator Mediator. Circ. Res. 2016, 119, 375-396. [CrossRef]

79. Cai, H.; Harrison, D.G. Endothelial dysfunction in cardiovascular diseases: The role of oxidant stress. Circ. Res. 2000, 87, 840-844. [CrossRef]

80. Barsacchi, R.; Perrotta, C.; Bulotta, S.; Moncada, S.; Borgese, N.; Clementi, E. Activation of endothelial nitric-oxide synthase by tumor necrosis factor-alpha: A novel pathway involving sequential activation of neutral sphingomyelinase, phosphatidylinositol-3' kinase, and Akt. Mol. Pharmacol. 2003, 63, 886-895. [CrossRef]

81. De Palma, C.; Meacci, E.; Perrotta, C.; Bruni, P.; Clementi, E. Endothelial nitric oxide synthase activation by tumor necrosis factor alpha through neutral sphingomyelinase 2, sphingosine kinase 1, and sphingosine 1 phosphate receptors: A novel pathway relevant to the pathophysiology of endothelium. Arterioscler. Thromb. Vasc. Biol. 2006, 26, 99-105. [CrossRef] [PubMed]

82. Symons, J.D.; Abel, E.D. Lipotoxicity contributes to endothelial dysfunction: A focus on the contribution from ceramide. Rev. Endocr. Metab. Disord. 2013, 14, 59-68. [CrossRef] [PubMed]

83. Smith, A.R.; Visioli, F.; Frei, B.; Hagen, T.M. Age-related changes in endothelial nitric oxide synthase phosphorylation and nitric oxide dependent vasodilation: Evidence for a novel mechanism involving sphingomyelinase and ceramide-activated phosphatase 2A. Aging Cell 2006, 5, 391-400. [CrossRef] [PubMed] 
84. Yang, Y.; Yin, J.; Baumgartner, W.; Samapati, R.; Solymosi, E.A.; Reppien, E.; Kuebler, W.M.; Uhlig, S. Platelet-activating factor reduces endothelial nitric oxide production: Role of acid sphingomyelinase. Eur.Respir. J. 2010, 36, 417-427. [CrossRef] [PubMed]

85. Maniatis, N.A.; Brovkovych, V.; Allen, S.E.; John, T.A.; Shajahan, A.N.; Tiruppathi, C.; Vogel, S.M.; Skidgel, R.A.; Malik, A.B.; Minshall, R.D. Novel mechanism of endothelial nitric oxide synthase activation mediated by caveolae internalization in endothelial cells. Circ. Res. 2006, 99, 870-877. [CrossRef] [PubMed]

86. Wu, Y.; Song, P.; Xu, J.; Zhang, M.; Zou, M.H. Activation of protein phosphatase 2A by palmitate inhibits AMP-activated protein kinase. J. Biol. Chem. 2007, 282, 9777-9788. [CrossRef]

87. Bharath, L.P.; Ruan, T.; Li, Y.; Ravindran, A.; Wan, X.; Nhan, J.K.; Walker, M.L.; Deeter, L.; Goodrich, R.; Johnson, E.; et al. Ceramide-Initiated Protein Phosphatase 2A Activation Contributes to Arterial Dysfunction In Vivo. Diabetes 2015, 64, 3914-3926. [CrossRef]

88. Zhang, Q.J.; Holland, W.L.; Wilson, L.; Tanner, J.M.; Kearns, D.; Cahoon, J.M.; Pettey, D.; Losee, J.; Duncan, B.; Gale, D.; et al. Ceramide mediates vascular dysfunction in diet-induced obesity by PP2A-mediated dephosphorylation of the eNOS-Akt complex. Diabetes 2012, 61, 1848-1859. [CrossRef]

89. Jin, S.; Zhang, Y.; Yi, F.; Li, P.L. Critical role of lipid raft redox signaling platforms in endostatin-induced coronary endothelial dysfunction. Arterioscler. Thromb. Vasc. Biol. 2008, 28, 485-490. [CrossRef]

90. Schutze, S.; Berkovic, D.; Tomsing, O.; Unger, C.; Kronke, M. Tumor necrosis factor induces rapid production of 1'2'diacylglycerol by a phosphatidylcholine-specific phospholipase C. J. Exp. Med. 1991, 174, 975-988. [CrossRef]

91. Vandanmagsar, B.; Youm, Y.H.; Ravussin, A.; Galgani, J.E.; Stadler, K.; Mynatt, R.L.; Ravussin, E.; Stephens, J.M.; Dixit, V.D. The NLRP3 inflammasome instigates obesity-induced inflammation and insulin resistance. Nat. Med. 2011, 17, 179-188. [CrossRef] [PubMed]

92. Sorbara, M.T.; Girardin, S.E. Mitochondrial ROS fuel the inflammasome. Cell Res. 2011, 21, 558-560. [CrossRef] [PubMed]

93. Koka, S.; Xia, M.; Chen, Y.; Bhat, O.M.; Yuan, X.; Boini, K.M.; Li, P.L. Endothelial NLRP3 inflammasome activation and arterial neointima formation associated with acid sphingomyelinase during hypercholesterolemia. Redox Biol. 2017, 13, 336-344. [CrossRef] [PubMed]

94. Aird, W.C. The role of the endothelium in severe sepsis and multiple organ dysfunction syndrome. Blood 2003, 101, 3765-3777. [CrossRef] [PubMed]

95. Brown, M.B.; Hunt, W.R.; Noe, J.E.; Rush, N.I.; Schweitzer, K.S.; Leece, T.C.; Moldobaeva, A.; Wagner, E.M.; Dudek, S.M.; Poirier, C.; et al. Loss of cystic fibrosis transmembrane conductance regulator impairs lung endothelial cell barrier function and increases susceptibility to microvascular damage from cigarette smoke. Pulm. Circ. 2014, 4, 260-268. [CrossRef] [PubMed]

96. Schweitzer, K.S.; Hatoum, H.; Brown, M.B.; Gupta, M.; Justice, M.J.; Beteck, B.; Van Demark, M.; Gu, Y.; Presson, R.G., Jr.; Hubbard, W.C.; et al. Mechanisms of lung endothelial barrier disruption induced by cigarette smoke: Role of oxidative stress and ceramides. Am. J. Physiol. Lung Cell Mol. Physiol. 2011, 301, L836-L846. [CrossRef] [PubMed]

97. Simmons, S.; Erfinanda, L.; Bartz, C.; Kuebler, W.M. Novel mechanisms regulating endothelial barrier function in the pulmonary microcirculation. J. Physiol. 2018. [CrossRef]

98. Goggel, R.; Winoto-Morbach, S.; Vielhaber, G.; Imai, Y.; Lindner, K.; Brade, L.; Brade, H.; Ehlers, S.; Slutsky, A.S.; Schutze, S.; et al. PAF-mediated pulmonary edema: A new role for acid sphingomyelinase and ceramide. Nat. Med. 2004, 10, 155-160. [CrossRef]

99. Kuebler, W.M.; Yang, Y.; Samapati, R.; Uhlig, S. Vascular barrier regulation by PAF, ceramide, caveolae, and $\mathrm{NO}$ - an intricate signaling network with discrepant effects in the pulmonary and systemic vasculature. Cell Physiol. Biochem. 2010, 26, 29-40. [CrossRef]

100. Sommer, N.; Huttemann, M.; Pak, O.; Scheibe, S.; Knoepp, F.; Sinkler, C.; Malczyk, M.; Gierhardt, M.; Esfandiary, A.; Kraut, S.; et al. Mitochondrial Complex IV Subunit 4 Isoform 2 Is Essential for Acute Pulmonary Oxygen Sensing. Circ. Res. 2017, 121, 424-438. [CrossRef]

101. Sylvester, J.T.; Shimoda, L.A.; Aaronson, P.I.; Ward, J.P. Hypoxic pulmonary vasoconstriction. Physiol. Rev. 2012, 92, 367-520. [CrossRef] [PubMed]

102. Waypa, G.B.; Schumacker, P.T. Hypoxic pulmonary vasoconstriction: Redox events in oxygen sensing. J. Appl. Physiol. 2005, 98, 404-414. [CrossRef] [PubMed] 
103. Weir, E.K.; Lopez-Barneo, J.; Buckler, K.J.; Archer, S.L. Acute oxygen-sensing mechanisms. N. Engl. J. Med. 2005, 353, 2042-2055. [CrossRef] [PubMed]

104. Aaronson, P.I.; Robertson, T.P.; Knock, G.A.; Becker, S.; Lewis, T.H.; Snetkov, V.; Ward, J.P. Hypoxic pulmonary vasoconstriction: Mechanisms and controversies. J. Physiol. 2006, 570, 53-58. [CrossRef]

105. Weir, E.K.; Archer, S.L. The mechanism of acute hypoxic pulmonary vasoconstriction: The tale of two channels. FASEB J. 1995, 9, 183-189. [CrossRef]

106. Waypa, G.B.; Chandel, N.S.; Schumacker, P.T. Model for hypoxic pulmonary vasoconstriction involving mitochondrial oxygen sensing. Circ. Res. 2001, 88, 1259-1266. [CrossRef] [PubMed]

107. Weissmann, N.; Dietrich, A.; Fuchs, B.; Kalwa, H.; Ay, M.; Dumitrascu, R.; Olschewski, A.; Storch, U.; Mederos y Schnitzler, M.; Ghofrani, H.A.; et al. Classical transient receptor potential channel 6 (TRPC6) is essential for hypoxic pulmonary vasoconstriction and alveolar gas exchange. Proc. Natl. Acad. Sci. USA 2006, 103, 19093-19098. [CrossRef]

108. Waypa, G.B.; Marks, J.D.; Guzy, R.; Mungai, P.T.; Schriewer, J.; Dokic, D.; Schumacker, P.T. Hypoxia triggers subcellular compartmental redox signaling in vascular smooth muscle cells. Circ. Res. 2010, 106, 526-535. [CrossRef]

109. Bourbon, N.A.; Yun, J.; Kester, M. Ceramide directly activates protein kinase C zeta to regulate a stressactivated protein kinase signaling complex. J. Biol. Chem. 2000, 275, 35617-35623. [CrossRef]

110. Cogolludo, A.; Moreno, L.; Bosca, L.; Tamargo, J.; Perez-Vizcaino, F. Thromboxane A2-induced inhibition of voltage-gated $\mathrm{K}+$ channels and pulmonary vasoconstriction: Role of protein kinase Czeta. Circ. Res. 2003, 93, 656-663. [CrossRef]

111. Cogolludo, A.; Moreno, L.; Lodi, F.; Tamargo, J.; Perez-Vizcaino, F. Postnatal maturational shift from PKCzeta and voltage-gated $\mathrm{K}+$ channels to RhoA/Rho kinase in pulmonary vasoconstriction. Cardiovasc. Res. 2005, 66, 84-93. [CrossRef] [PubMed]

112. Robertson, T.P.; Dipp, M.; Ward, J.P.; Aaronson, P.I.; Evans, A.M. Inhibition of sustained hypoxic vasoconstriction by Y-27632 in isolated intrapulmonary arteries and perfused lung of the rat. Br. J. Pharmacol. 2000, 131, 5-9. [CrossRef]

113. Firth, A.L.; Gordienko, D.V.; Yuill, K.H.; Smirnov, S.V. Cellular localization of mitochondria contributes to $\mathrm{Kv}$ channel-mediated regulation of cellular excitability in pulmonary but not mesenteric circulation. Am. J. Physiol. Lung Cell Mol. Physiol. 2009, 296, L347-L360. [CrossRef]

114. Clyman, R.I. Mechanisms regulating the ductus arteriosus. Biol. Neonate 2006, 89, 330-335. [CrossRef] [PubMed]

115. Michelakis, E.; Rebeyka, I.; Bateson, J.; Olley, P.; Puttagunta, L.; Archer, S. Voltage-gated potassium channels in human ductus arteriosus. Lancet 2000, 356, 134-137. [CrossRef]

116. Michelakis, E.D.; Rebeyka, I.; Wu, X.; Nsair, A.; Thebaud, B.; Hashimoto, K.; Dyck, J.R.; Haromy, A.; Harry, G.; Barr, A.; et al. $\mathrm{O}_{2}$ sensing in the human ductus arteriosus: Regulation of voltage-gated $\mathrm{K}+$ channels in smooth muscle cells by a mitochondrial redox sensor. Circ. Res. 2002, 91, 478-486. [CrossRef]

117. Cogolludo, A.L.; Moral-Sanz, J.; van der Sterren, S.; Frazziano, G.; van Cleef, A.N.; Menendez, C.; Zoer, B.; Moreno, E.; Roman, A.; Perez-Vizcaino, F.; et al. Maturation of $\mathrm{O}_{2}$ sensing and signaling in the chicken ductus arteriosus. Am. J. Physiol. Lung Cell Mol. Physiol. 2009, 297, L619-L630. [CrossRef]

118. Olschewski, A.; Hong, Z.; Peterson, D.A.; Nelson, D.P.; Porter, V.A.; Weir, E.K. Opposite effects of redox status on membrane potential, cytosolic calcium, and tone in pulmonary arteries and ductus arteriosus. Am. J. Physiol. Lung Cell Mol. Physiol. 2004, 286, L15-L22. [CrossRef] [PubMed]

119. Hong, Z.; Hong, F.; Olschewski, A.; Cabrera, J.A.; Varghese, A.; Nelson, D.P.; Weir, E.K. Role of store-operated calcium channels and calcium sensitization in normoxic contraction of the ductus arteriosus. Circulation 2006, 114, 1372-1379. [CrossRef]

120. Kajimoto, H.; Hashimoto, K.; Bonnet, S.N.; Haromy, A.; Harry, G.; Moudgil, R.; Nakanishi, T.; Rebeyka, I.; Thebaud, B.; Michelakis, E.D.; et al. Oxygen activates the Rho/Rho-kinase pathway and induces RhoB and ROCK-1 expression in human and rabbit ductus arteriosus by increasing mitochondria-derived reactive oxygen species: A newly recognized mechanism for sustaining ductal constriction. Circulation 2007, 115, 1777-1788. [CrossRef]

121. Czarny, M.; Liu, J.; Oh, P.; Schnitzer, J.E. Transient mechanoactivation of neutral sphingomyelinase in caveolae to generate ceramide. J. Biol. Chem. 2003, 278, 4424-4430. [CrossRef] [PubMed] 
122. Czarny, M.; Schnitzer, J.E. Neutral sphingomyelinase inhibitor scyphostatin prevents and ceramide mimics mechanotransduction in vascular endothelium. Am. J. Physiol. Heart Circ. Physiol. 2004, 287, H1344-H1352. [CrossRef] [PubMed]

123. Freed, J.K.; Durand, M.J.; Hoffmann, B.R.; Densmore, J.C.; Greene, A.S.; Gutterman, D.D. Mitochondria-regulated formation of endothelium-derived extracellular vesicles shifts the mediator of flow-induced vasodilation. Am. J. Physiol. Heart Circ. Physiol. 2017, 312, H1096-H1104. [CrossRef] [PubMed]

124. Yu, F.P.S.; Amintas, S.; Levade, T.; Medin, J.A. Acid ceramidase deficiency: Farber disease and SMA-PME. Orphanet J. Rare Dis. 2018, 13, 121. [CrossRef] [PubMed]

125. Schuchman, E.H. Acid ceramidase and the treatment of ceramide diseases: The expanding role of enzyme replacement therapy. Biochim. Biophys. Acta 2016, 1862, 1459-1471. [CrossRef] [PubMed]

126. Gilbert-Barness, E. Cardiovascular involvement in metabolic diseases. Pediatr. Pathol. Mol. Med. 2002, 21, 93-136. [CrossRef] [PubMed]

127. Lewis, A.C.; Wallington-Beddoe, C.T.; Powell, J.A.; Pitson, S.M. Targeting sphingolipid metabolism as an approach for combination therapies in haematological malignancies. Cell Death Discov. 2018, 5, 4. [CrossRef] [PubMed]

128. Ogretmen, B. Sphingolipid metabolism in cancer signalling and therapy. Nat. Rev. Cancer 2018, 18, 33-50. [CrossRef] [PubMed]

129. Dinoff, A.; Herrmann, N.; Lanctot, K.L. Ceramides and depression: A systematic review. J. Affect. Disord. 2017, 213, 35-43. [CrossRef]

130. Ong, W.Y.; Herr, D.R.; Farooqui, T.; Ling, E.A.; Farooqui, A.A. Role of sphingomyelinases in neurological disorders. Expert Opin. Ther. Targets 2015, 19, 1725-1742. [CrossRef]

131. Baker, J.E.; Boudreau, R.M.; Seitz, A.P.; Caldwell, C.C.; Gulbins, E.; Edwards, M.J. Sphingolipids and Innate Immunity: A New Approach to Infection in the Post-Antibiotic Era? Surg. Infect. 2018. [CrossRef] [PubMed]

132. Huang, F.C. The Role of Sphingolipids on Innate Immunity to Intestinal Salmonella Infection. Int. J. Mol. Sci. 2017, 18. [CrossRef] [PubMed]

133. Norris, G.H.; Blesso, C.N. Dietary and Endogenous Sphingolipid Metabolism in Chronic Inflammation. Nutrients 2017, 9. [CrossRef]

134. Maceyka, M.; Spiegel, S. Sphingolipid metabolites in inflammatory disease. Nature 2014, 510, 58-67. [CrossRef] [PubMed]

135. Sletten, A.C.; Peterson, L.R.; Schaffer, J.E. Manifestations and mechanisms of myocardial lipotoxicity in obesity. J. Intern. Med. 2018, 284, 478-491. [CrossRef]

136. Cruciani-Guglielmacci, C.; Lopez, M.; Campana, M.; le Stunff, H. Brain Ceramide Metabolism in the Control of Energy Balance. Front. Physiol. 2017, 8, 787. [CrossRef] [PubMed]

137. Chavez, J.A.; Summers, S.A. A ceramide-centric view of insulin resistance. Cell Metab. 2012, 15, 585-594. [CrossRef]

138. Meikle, P.J.; Summers, S.A. Sphingolipids and phospholipids in insulin resistance and related metabolic disorders. Nat. Rev. Endocrinol. 2017, 13, 79-91. [CrossRef]

139. Schulze, P.C.; Drosatos, K.; Goldberg, I.J. Lipid Use and Misuse by the Heart. Circ. Res. 2016, 118, $1736-1751$. [CrossRef]

140. Summers, S.A. Could Ceramides Become the New Cholesterol? Cell Metab. 2018, 27, 276-280. [CrossRef]

141. Tippetts, T.S.; Holland, W.L.; Summers, S.A. The ceramide ratio: A predictor of cardiometabolic risk. J. Lipid Res. 2018, 59, 1549-1550. [CrossRef] [PubMed]

142. Borodzicz, S.; Czarzasta, K.; Kuch, M.; Cudnoch-Jedrzejewska, A. Sphingolipids in cardiovascular diseases and metabolic disorders. Lipids Health Dis. 2015, 14, 55. [CrossRef] [PubMed]

143. Robciuc, A.; Hyotylainen, T.; Jauhiainen, M.; Holopainen, J.M. Ceramides in the pathophysiology of the anterior segment of the eye. Curr. Eye Res. 2013, 38, 1006-1016. [CrossRef] [PubMed]

144. Li, S.; Ganguli-Indra, G.; Indra, A.K. Lipidomic analysis of epidermal lipids: A tool to predict progression of inflammatory skin disease in humans. Expert Rev. Proteomics 2016, 13, 451-456. [CrossRef] [PubMed]

145. Borodzicz, S.; Rudnicka, L.; Mirowska-Guzel, D.; Cudnoch-Jedrzejewska, A. The role of epidermal sphingolipids in dermatologic diseases. Lipids Health Dis. 2016, 15, 13. [CrossRef] [PubMed] 
146. Tarasov, K.; Ekroos, K.; Suoniemi, M.; Kauhanen, D.; Sylvanne, T.; Hurme, R.; Gouni-Berthold, I.; Berthold, H.K.; Kleber, M.E.; Laaksonen, R.; et al. Molecular lipids identify cardiovascular risk and are efficiently lowered by simvastatin and PCSK9 deficiency. J. Clin. Endocrinol. Metab. 2014, 99, E45-E52. [CrossRef] [PubMed]

147. Havulinna, A.S.; Sysi-Aho, M.; Hilvo, M.; Kauhanen, D.; Hurme, R.; Ekroos, K.; Salomaa, V.; Laaksonen, R. Circulating Ceramides Predict Cardiovascular Outcomes in the Population-Based FINRISK 2002 Cohort. Arterioscler. Thromb. Vasc. Biol. 2016, 36, 2424-2430. [CrossRef]

148. Wang, D.D.; Toledo, E.; Hruby, A.; Rosner, B.A.; Willett, W.C.; Sun, Q.; Razquin, C.; Zheng, Y.; Ruiz-Canela, M.; Guasch-Ferre, M.; et al. Plasma Ceramides, Mediterranean Diet, and Incident Cardiovascular Disease in the PREDIMED Trial (Prevencion con Dieta Mediterranea). Circulation 2017, 135, 2028-2040. [CrossRef]

149. Mantovani, A.; Bonapace, S.; Lunardi, G.; Salgarello, M.; Dugo, C.; Canali, G.; Byrne, C.D.; Gori, S.; Barbieri, E.; Targher, G. Association between plasma ceramides and inducible myocardial ischemia in patients with established or suspected coronary artery disease undergoing myocardial perfusion scintigraphy. Metabolism 2018, 85, 305-312. [CrossRef]

150. Anroedh, S.; Hilvo, M.; Akkerhuis, K.M.; Kauhanen, D.; Koistinen, K.; Oemrawsingh, R.; Serruys, P.; van Geuns, R.J.; Boersma, E.; Laaksonen, R.; et al. Plasma concentrations of molecular lipid species predict long-term clinical outcome in coronary artery disease patients. J. Lipid Res. 2018, 59, 1729-1737. [CrossRef]

151. Laaksonen, R.; Ekroos, K.; Sysi-Aho, M.; Hilvo, M.; Vihervaara, T.; Kauhanen, D.; Suoniemi, M.; Hurme, R.; Marz, W.; Scharnagl, H.; et al. Plasma ceramides predict cardiovascular death in patients with stable coronary artery disease and acute coronary syndromes beyond LDL-cholesterol. Eur. Heart J. 2016, 37, 1967-1976. [CrossRef] [PubMed]

152. Alshehry, Z.H.; Mundra, P.A.; Barlow, C.K.; Mellett, N.A.; Wong, G.; McConville, M.J.; Simes, J.; Tonkin, A.M.; Sullivan, D.R.; Barnes, E.H.; et al. Plasma Lipidomic Profiles Improve on Traditional Risk Factors for the Prediction of Cardiovascular Events in Type 2 Diabetes Mellitus. Circulation 2016, 134, 1637-1650. [CrossRef] [PubMed]

153. de Carvalho, L.P.; Tan, S.H.; Ow, G.S.; Tang, Z.; Ching, J.; Kovalik, J.P.; Poh, S.C.; Chin, C.T.; Richards, A.M.; Martinez, E.C.; et al. Plasma Ceramides as Prognostic Biomarkers and Their Arterial and Myocardial Tissue Correlates in Acute Myocardial Infarction. JACC Basic Transl. Sci. 2018, 3, 163-175. [CrossRef] [PubMed]

154. Kaur, J. A comprehensive review on metabolic syndrome. Cardiol. Res. Pract. 2014, 2014. [CrossRef] [PubMed]

155. Chaurasia, B.; Summers, S.A. Ceramides-Lipotoxic Inducers of Metabolic Disorders. Trends Endocrinol. Metab. 2015, 26, 538-550. [CrossRef] [PubMed]

156. Tabassum, R.; Rämö, J.T.; Ripatti, P.; Koskela, J.T.; Kurki, M.; Karjalainen, J.; Hassan, S.; Nunez-Fontarnau, J.; Kiiskinen, T.T.; Söderlund, S. Genetics of human plasma lipidome: Understanding lipid metabolism and its link to diseases beyond traditional lipids. bioRxiv 2018, 457960. [CrossRef]

157. Wheeler, E.; Leong, A.; Liu, C.T.; Hivert, M.F.; Strawbridge, R.J.; Podmore, C.; Li, M.; Yao, J.; Sim, X.; Hong, J.; et al. Impact of common genetic determinants of Hemoglobin A1c on type 2 diabetes risk and diagnosis in ancestrally diverse populations: A transethnic genome-wide meta-analysis. PLoS Med. 2017, 14, e1002383. [CrossRef]

158. Wigger, L.; Cruciani-Guglielmacci, C.; Nicolas, A.; Denom, J.; Fernandez, N.; Fumeron, F.; Marques-Vidal, P.; Ktorza, A.; Kramer, W.; Schulte, A. Plasma dihydroceramides are diabetes susceptibility biomarker candidates in mice and humans. Cell Rep. 2017, 18, 2269-2279. [CrossRef] [PubMed]

159. Lemaitre, R.N.; Yu, C.; Hoofnagle, A.; Hari, N.; Jensen, P.; Fretts, A.M.; Umans, J.G.; Howard, B.V.; Sitlani, C.M.; Siscovick, D.S. Circulating Sphingolipids, Insulin, HOMA-IR and HOMA-B: The Strong Heart Family Study. Diabetes 2018, 68. [CrossRef]

160. Park, T.S.; Goldberg, I.J. Sphingolipids, lipotoxic cardiomyopathy, and cardiac failure. Heart Fail Clin. 2012, 8 , 633-641. [CrossRef]

161. Liu, Y.; Neumann, D.; Glatz, J.F.; Luiken, J.J. Molecular mechanism of lipid-induced cardiac insulin resistance and contractile dysfunction. Prostaglandins Leukot. Essent. Fatty Acids 2016, 136, 131-141. [CrossRef] [PubMed]

162. Holland, W.L.; Summers, S.A. Strong Heart, Low Ceramides. Diabetes 2018, 67, 1457-1460. [CrossRef] [PubMed] 
163. Uhlig, S.; Gulbins, E. Sphingolipids in the lungs. Am. J. Respir. Crit. Care Med. 2008, 178, 1100-1114. [CrossRef] [PubMed]

164. Uhlig, S.; Yang, Y. Sphingolipids in acute lung injury. Handb. Exp. Pharmacol. 2013, 227-246. [CrossRef]

165. Bull, T.M.; Clark, B.; McFann, K.; Moss, M. Pulmonary vascular dysfunction is associated with poor outcomes in patients with acute lung injury. Am. J. Respir. Crit. Care Med. 2010, 182, 1123-1128. [CrossRef] [PubMed]

166. Price, L.C.; Wort, S.J.; Finney, S.J.; Marino, P.S.; Brett, S.J. Pulmonary vascular and right ventricular dysfunction in adult critical care: Current and emerging options for management: A systematic literature review. Crit. Care 2010, 14, R169. [CrossRef] [PubMed]

167. Claus, R.A.; Bunck, A.C.; Bockmeyer, C.L.; Brunkhorst, F.M.; Losche, W.; Kinscherf, R.; Deigner, H.P. Role of increased sphingomyelinase activity in apoptosis and organ failure of patients with severe sepsis. FASEB J. 2005, 19, 1719-1721. [CrossRef] [PubMed]

168. Guo, L.; Tan, G.; Liu, P.; Li, H.; Tang, L.; Huang, L.; Ren, Q. Three plasma metabolite signatures for diagnosing high altitude pulmonary edema. Sci. Rep. 2015, 5, 15126. [CrossRef]

169. von Bismarck, P.; Wistadt, C.F.; Klemm, K.; Winoto-Morbach, S.; Uhlig, U.; Schutze, S.; Adam, D.; Lachmann, B.; Uhlig, S.; Krause, M.F. Improved pulmonary function by acid sphingomyelinase inhibition in a newborn piglet lavage model. Am. J. Respir. Crit. Care Med. 2008, 177, 1233-1241. [CrossRef]

170. Yang, J.; Qu, J.M.; Summah, H.; Zhang, J.; Zhu, Y.G.; Jiang, H.N. Protective effects of imipramine in murine endotoxin-induced acute lung injury. Eur. J. Pharmacol. 2010, 638, 128-133. [CrossRef]

171. Laube, M.; Amann, E.; Uhlig, U.; Yang, Y.; Fuchs, H.W.; Zemlin, M.; Mercier, J.C.; Maier, R.F.; Hummler, H.D.; Uhlig, S.; et al. Inflammatory Mediators in Tracheal Aspirates of Preterm Infants Participating in a Randomized Trial of Inhaled Nitric Oxide. PLOS ONE 2017, 12, e0169352. [CrossRef] [PubMed]

172. van Mastrigt, E.; Zweekhorst, S.; Bol, B.; Tibboel, J.; van Rosmalen, J.; Samsom, J.N.; Kroon, A.A.; de Jongste, J.C.; Reiss, I.K.M.; Post, M.; et al. Ceramides in tracheal aspirates of preterm infants: Marker for bronchopulmonary dysplasia. PLoS ONE 2018, 13, e0185969. [CrossRef] [PubMed]

173. Snoek, K.G.; Reiss, I.K.; Tibboel, J.; van Rosmalen, J.; Capolupo, I.; van Heijst, A.; Schaible, T.; Post, M.; Tibboel, D. Sphingolipids in Congenital Diaphragmatic Hernia; Results from an International Multicenter Study. PLoS ONE 2016, 11, e0155136. [CrossRef] [PubMed]

174. Chen, J.; Tang, H.; Sysol, J.R.; Moreno-Vinasco, L.; Shioura, K.M.; Chen, T.; Gorshkova, I.; Wang, L.; Huang, L.S.; Usatyuk, P.V.; et al. The sphingosine kinase 1/sphingosine-1-phosphate pathway in pulmonary arterial hypertension. Am. J. Respir. Crit. Care Med. 2014, 190, 1032-1043. [CrossRef] [PubMed]

175. Brittain, E.L.; Talati, M.; Fessel, J.P.; Zhu, H.; Penner, N.; Calcutt, M.W.; West, J.D.; Funke, M.; Lewis, G.D.; Gerszten, R.E.; et al. Fatty Acid Metabolic Defects and Right Ventricular Lipotoxicity in Human Pulmonary Arterial Hypertension. Circulation 2016, 133, 1936-1944. [CrossRef] [PubMed]

176. Guilbault, C.; Wojewodka, G.; Saeed, Z.; Hajduch, M.; Matouk, E.; De Sanctis, J.B.; Radzioch, D. Cystic fibrosis fatty acid imbalance is linked to ceramide deficiency and corrected by fenretinide. Am. J. Respir. Cell Mol. Biol. 2009, 41, 100-106. [CrossRef] [PubMed]

177. Garic, D.; De Sanctis, J.B.; Wojewodka, G.; Houle, D.; Cupri, S.; Abu-Arish, A.; Hanrahan, J.W.; Hajduch, M.; Matouk, E.; Radzioch, D. Fenretinide differentially modulates the levels of long- and very long-chain ceramides by downregulating Cers5 enzyme: Evidence from bench to bedside. J. Mol. Med. 2017, 95, 1053-1064. [CrossRef]

178. Brodlie, M.; McKean, M.C.; Johnson, G.E.; Gray, J.; Fisher, A.J.; Corris, P.A.; Lordan, J.L.; Ward, C. Ceramide is increased in the lower airway epithelium of people with advanced cystic fibrosis lung disease. Am. J. Respir. Crit. Care Med. 2010, 182, 369-375. [CrossRef]

179. Lea, S.R.; Metcalfe, H.J.; Plumb, J.; Beerli, C.; Poll, C.; Singh, D.; Abbott-Banner, K.H. Neutral sphingomyelinase-2, acid sphingomyelinase, and ceramide levels in COPD patients compared to controls. Int. J. Chron. Obstruct. Pulmon. Dis. 2016, 11, 2139-2147. [CrossRef]

180. Scarpa, M.C.; Baraldo, S.; Marian, E.; Turato, G.; Calabrese, F.; Saetta, M.; Maestrelli, P. Ceramide expression and cell homeostasis in chronic obstructive pulmonary disease. Respiration 2013, 85, 342-349. [CrossRef]

181. Bowler, R.P.; Jacobson, S.; Cruickshank, C.; Hughes, G.J.; Siska, C.; Ory, D.S.; Petrache, I.; Schaffer, J.E.; Reisdorph, N.; Kechris, K. Plasma sphingolipids associated with chronic obstructive pulmonary disease phenotypes. Am. J. Respir. Crit. Care Med. 2015, 191, 275-284. [CrossRef] [PubMed] 
182. Mourani, P.M.; Sontag, M.K.; Younoszai, A.; Miller, J.I.; Kinsella, J.P.; Baker, C.D.; Poindexter, B.B.; Ingram, D.A.; Abman, S.H. Early pulmonary vascular disease in preterm infants at risk for bronchopulmonary dysplasia. Am. J. Respir. Crit. Care Med. 2015, 191, 87-95. [CrossRef] [PubMed]

183. Simonneau, G.; Galie, N.; Rubin, L.J.; Langleben, D.; Seeger, W.; Domenighetti, G.; Gibbs, S.; Lebrec, D.; Speich, R.; Beghetti, M.; et al. Clinical classification of pulmonary hypertension. J. Am. Coll. Cardiol. 2004, 43, 5S-12S. [CrossRef] [PubMed]

184. Byun, H.S.; Pyne, S.; Macritchie, N.; Pyne, N.J.; Bittman, R. Novel sphingosine-containing analogues selectively inhibit sphingosine kinase (SK) isozymes, induce SK1 proteasomal degradation and reduce DNA synthesis in human pulmonary arterial smooth muscle cells. Medchemcomm 2013, 4. [CrossRef] [PubMed]

185. Gairhe, S.; Joshi, S.R.; Bastola, M.M.; McLendon, J.M.; Oka, M.; Fagan, K.A.; McMurtry, I.F. Sphingosine-1-phosphate is involved in the occlusive arteriopathy of pulmonary arterial hypertension. Pulm. Circ. 2016, 6, 369-380. [CrossRef] [PubMed]

186. Zhao, Y.D.; Chu, L.; Lin, K.; Granton, E.; Yin, L.; Peng, J.; Hsin, M.; Wu, L.; Yu, A.; Waddell, T.; et al. A Biochemical Approach to Understand the Pathogenesis of Advanced Pulmonary Arterial Hypertension: Metabolomic Profiles of Arginine, Sphingosine-1-Phosphate, and Heme of Human Lung. PLoS ONE 2015, 10, e0134958. [CrossRef] [PubMed]

187. Hayes, D., Jr.; Tobias, J.D.; Mansour, H.M.; Kirkby, S.; McCoy, K.S.; Daniels, C.J.; Whitson, B.A. Pulmonary hypertension in cystic fibrosis with advanced lung disease. Am. J. Respir. Crit. Care Med. 2014, 190, 898-905. [CrossRef]

188. Minai, O.A.; Chaouat, A.; Adnot, S. Pulmonary hypertension in COPD: Epidemiology, significance, and management: Pulmonary vascular disease: The global perspective. Chest 2010, 137, 39S-51S. [CrossRef]

189. Filosto, S.; Castillo, S.; Danielson, A.; Franzi, L.; Khan, E.; Kenyon, N.; Last, J.; Pinkerton, K.; Tuder, R.; Goldkorn, T. Neutral sphingomyelinase 2: A novel target in cigarette smoke-induced apoptosis and lung injury. Am. J. Respir Cell Mol. Biol. 2011, 44, 350-360. [CrossRef]

(C) 2019 by the authors. Licensee MDPI, Basel, Switzerland. This article is an open access article distributed under the terms and conditions of the Creative Commons Attribution (CC BY) license (http://creativecommons.org/licenses/by/4.0/). 